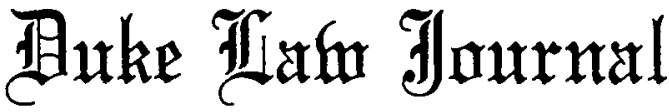

VOLUME 1978

DECEMBER

NUMBER 5

\section{THE REGULATION OF COMMODITY OPTIONS}

\author{
ROBERT C. LOWER*
}

The Commodity Futures Trading Commission ${ }^{1}$ (CFTC) is currently considering the implementation of a pilot program for commod-

(C) 1979 Robert C. Lower.

* A.B. 1969, Harvard College; J.D. 1972, Harvard Law School; Member, Georgia Bar; Partner, Alston, Miller \& Gaines, Atlanta, Ga. and Washington, D.C.

THE FOLLOWING CITATIONS WILL BE USED IN THIS ARTICLE:

Extend Commodity Exchange Act: Hearings Before the Subcomm. on Conservation and Credit of the House Comm. on Agriculture, 95th Cong., 2d Sess. (1978) [hereinafter cited as 1978 House Hearings];

Agriculture, Rural Development and Related Agencies Appropriations for 1979: Hearings Before a Subcomm. of the Comm. on Appropriations, 95th Cong., 2d Sess. (1978) [hereinafter cited as 1978 House Appropriation Hearings];

Reauthorization of the Commodity Futures Trading Commission: Hearings Before the Subcomm. on Agricultural Research and General Legislation of the Senate Comm. on Agriculture, Nutrition and Forestry, 95th Cong., 2d Sess. (1978) [hereinafter cited as 1978 Senate Hearings];

Commodity Futures Trading Commission Act of 1974: Hearings on H.R. 11955 Before the House Comm. on Agriculiure, 93d Cong., 2d Sess. (1974) [hereinafter cited as 1974 House Hearings];

Commodity Futures Trading Commission Act: Hearings Before the Senate Comm. on Agriculture and Forestry, 93d Cong., 2d Sess. (1974) [hereinafter cited as 1974 Senate Hearings];

Hearings on H.R. 6772 to Amend the Grain Futures Act Before the Senate Comm. on Agriculture and Forestry, 74th Cong., 2d Sess. (1936) [hereinafter cited as 1936 Hearings];

Recommended Policies on Commodity Option Transactions: Report of the AdviSORY Committee on the Definition and Regulation of MaRket Instruments to the COMMODITY FuturEs TRADING COMMISSION (July 6, 1976) [hereinafter cited as ADVISORY COMMITTEE REPORT];

P. Mehl, Trading in Privileges on the Chicago Board of Trade (U.S. Dep't of Agriculture Cir. No. 323, 1934) [hereinafter cited as MEHL];

Long, Commodity Options Revisited, 25 DRAKE L. Rev. 75 (1975) [hereinafter cited as Long];

W. Baumol, Commodity Options: On Their Contribution to the Economy (Sept. 1973) [hereinafter cited as Baumol];

L. Kendall, The Chicago Board of Trade and the Federal Government: A Study of Their Relationship, 1848 to 1952 (1956) (unpublished dissertation on file at Univ. of Indiana Business School) [hereinafter cited as Kendall];

J. Lurie, The Chicago Board of Trade, 1874-1905, and the Development of Certain Rules and Regulations Governing Its Operation (1970) (unpublished Ph.D. thesis, Univ. of Wis., on file in library of Chicago Board of Trade) [hereinafter cited as Lurie].

1. The Commission was created by the Commodity Futures Trading Commission Act of 1974, 7 U.S.C. $\$ \S 1-22$ (1976) (amending 7 U.S.C. $\$ \S 1-17 b$ (1970)). 
ity option trading ${ }^{2}$ in the United States. Used in conjunction with the commodity futures markets, ${ }^{3}$ commodity options have been criticized by many as nothing more than aleatory contracts used to wager on

2. The commodity option is, in theory, no different from the more familiar types of option contracts relating to real estate, securities or personal services. Essentially, an option is a right that is purchased by the option holder entitling him either to buy from or to sell to the grantor of the option the subject of the option at a stated price and within a stated time. In the case of a commodity option, the right pertains to an underlying physical commodity (such as a specific quantity of gold, a train carload of coffee, etc.) or to a commodity futures contract relating to that commodity. The price paid for the option right is referred to as the "premium," and the price at which the option purchaser is entitled to buy or sell the underlying commodity or futures contract is referred to as the "striking price." "Exercise" is the decision of an option holder to require performance by the grantor of his obligation with respect to the underlying commodity or futures contract. The period during which an option may be exercised is specified in the contract and may range from one day to as long as 18 months. The "exercise date" or "expiration date" is the final day on which the option holder may exercise the option.

If the option entitles its holder to purchase the underlying commodity or futures contract from the grantor, it is referred to as a "call" option. If the object of the call option is a futures contract, this means that upon exercise of the option, the grantor will sell the futures contract to the grantee. In the terminology of futures trading, the option grantor thus would take a "short" or seller's position and the option holder would take a "long" or buyer's position under the futures contract. If, on the other hand, the option holder has the right to sell the underlying commodity or futures contract to the grantor, it is referred to as a "put" option. If the object of the put option is a futures contract, this means that upon exercise, the grantor has agreed to purchase a futures contract (and takes a "long" or buyer's position) from the grantee (who takes a "short" or seller's position).

There is a third type of commodity option contract which represents a combination of the call and put options described above. This is the "double option" which allows the grantee at his election either to buy from or to sell to the grantor (but not both) the underlying commodity or futures contract at a single striking price. The double option allows its holder to benefit from either a rise or a fall in prices of the underlying commodity. However, because it is really two options in one contract, the premium is usually twice that of the separate put or call contract. Such options are used when the trader expects high price volatility, but is unsure which way the prices will move. See Cornish, Types of Trading, in GetTing Started in London CommodiTIES 29 (2d ed. 1975).

3. Although not all commodity options are related to an underlying futures contract, it is still important to understand the relationship between the two. A futures contract is a standardized agreement for future delivery of a specified quantity of a commodity during a specific future delivery month. Such contracts are traded in the designated areas or "pits" of the commodity futures exchanges or boards of trade where the price of each contract is determined between buyers and sellers at public outcry. Once a transaction is completed, both parties are bound to perform in accordance with the terms of the contract.

While a commodity futures contract constitutes a mutual obligation under which the seller of a contract is obligated to sell the underlying commodity and the purchaser of the contract is obligated to purchase that commodity at the stated price and time, an option constitutes a unilateral contract -only the grantor has a binding obligation to perform. The option holder, on the other hand, may choose to exercise the option or not, depending upon whether it becomes economically advantageous for him to do so. Since the premium paid is a separate payment and does not constitute a credit against the striking price, an option holder will not break even on his investment unless the price of the underlying commodity or futures contract moves favorably by at least the amount of the premium plus commissions. If the price does move favorably, the holder will probably choose to exercise the option, thereby requiring the grantor to fulfill the terms of the 
commodity price changes. ${ }^{4}$ However, this attitude ignores the legitimate economic benefits that theoretically can accrue from commodity option trading. By generating empirical evidence that will reveal the true function of options in commodity trading and whether they serve any purpose not currently provided by futures trading, the proposed pilot program should ideally furnish the CFTC with a basis for determining whether trading in commodity options on domestic exchanges in the United States should be permanently established. However, the program has two basic problems in its current state. First, it is highly questionable whether the program's restrictions on options will allow them to demonstrate their true economic benefit. Second, the CFTC has not yet developed standards to review the empirical data to be collected by the program. This Article addresses both of these problems.

The Article will first discuss federal efforts to regulate commodity option trading-the most recent such effort culminating in the Commodity Futures Trading Commission Act of $1974 .^{5}$ It will then focus on this Act, paying particular attention to the activities of the independent commission created thereunder and to the reasons that led that Commission to impose an absolute ban on option trading as of June 1, 1978. ${ }^{6}$ Third, the Article will review the proposed pilot program to determine whether it is designed to provide an accurate ap-

contract. Even if the price moves favorably by only 25 or $30 \%$ of his premium amount, an option holder will probably exercise the option to recoup that portion of his expenditure. If a call option is exercised, the option grantor must sell to the holder the specified commodity or futures contract for the striking price. In the case of a put option, the option grantor must buy the underlying commodity or futures contract from the option holder and must pay the specified striking price.

In addition, there are a number of important practical distinctions between commodity options and commodity futures contracts. For example, when a party enters into a futures contract, whether he is a buyer or seller of that contract, he is required by the exchange on which the contract is traded to post margin deposits to guarantee his performance under the contract. When the market price of the particular futures contract changes during subsequent trading by more than a certain amount, the exchange and/or its clearinghouse will call for additional deposits, often referred to as a "maintenance margin," to be made by the party against whom the price has moved. Such adjustments are made on a daily basis throughout the life of each futures contract. An option contract, on the other hand, involves no obligation to make additional margin deposits in the event of adverse price changes. The option purchaser pays a premium at the time of purchase, but undertakes no risk of margin calls. If adverse price changes occur, the option holder merely fails to exercise his option. Unlike the holder of a futures contract, the option holder bears a risk of loss limited to the amount paid as option premium. This limitation of risk, in fact, is the factor that has made options very popular with small investors in the 1970s. For a discussion of margin requirements for futures trading, see CHICAGo BOARD OF TRADE, COMMODITY TRADING MANUAL 27-30, 128-30 (1977).

4. See, e.g., 1978 House Hearings 508 (statement of Linly R. Stum).

5. 7 U.S.C. $\$ \$ 1-22(1976)$.

6. 43 Fed. Reg. 16,153 (1978) (to be codified in 17 C.F.R. $\$ 32.11$ ). 
praisal of the potential economic benefits of option trading. The Article then offers suggestions for streamlining the program so that data gathering will not be impeded. Finally, it will suggest appropriate standards for evaluating the empirical evidence generated by the program and for determining whether the Commission should permit the regulated trading to continue on a permanent basis.

\section{Federal Regulation of Commodity Option Trading}

For 100 years, ever since the appearance of privilege trading on the floor of the Board of Trade of the City of Chicago (Chicago Board of Trade), ${ }^{7}$ the commodity trading industry has alternately avoided and been subjected to state and federal regulation. In the absence of such regulation, the industry became susceptible to abusive practices and manipulations, both imagined and real. Recurrent scandals led to the passage of the Commodity Exchange Act $^{8}$ of 1936, in which Congress enacted ostensibly comprehensive legislation which cured the evils of option trading by banning it. For some thirty years, Congress had apparently succeeded. However, in the early 1970 s, hybrid forms of commodity option trading that were outside the scope of any regulation appeared. True to their heritage, these unregulated options proved subject to abuse. In 1974, Congress amended the 1936 Act to eliminate these abuses.

In addition to expanding the scope of regulation of option and futures trading, the Commodity Futures Trading Commission Act of $1974^{9}$ created the CFTC. Congress charged the Commission with determining the fate of commodity option trading on domestic exchanges in the United States. ${ }^{10}$ To understand fully this congressional mandate,

7. See Ment 5. Privilege trading became popular among traders during the volatile markets of the early 1860s. They appear to have been used as a form of "hedging," whereby the holder of a futures position with a substantial risk of adverse price movement could limit that risk by obtaining the right to dispose of the position at a fixed price. Lurie 31 .

Despite their popularity, privileges apparently were already subject to controversy by 1865 . As described by an early historian of the Board of Trade, the rules of the exchange adopted in 1865 made specific mention of trading in privileges:

What are known as "puts" and "call" were discountenanced by the closing paragraph of Rule XI, which ran as follows: "Privileges bought or sold to deliver or call for grain or other property by members of the Association shall not be recognized as a business transaction by the Directors or Committee of Arbitration." Dealing in these privileges, however, though not recognized, does not appear to have been forbidden.

C. TAylor, History of the Board of TRAde of the City of Chicago 332 (1917). This provision was eliminated from the rules of the Board by 1869. MEHL 5 .

8. Ch. 545,49 Stat. 1491 (1936) (current version at 7 U.S.C. $\S \S 1-22$ (1976)).

9. 7 U.S.C. $\$ \S 1-22$ (1976).

10. Several additional responsibilities of the Commission are mentioned in the text accompanying notes 73-74 infra. 
one must begin with the 1936 Act—not only because the 1974 legislation was an amendment of that Act, but also because many of the concerns expressed prior to the 1936 Act remained and in part set the stage for the 1974 enactment.

\section{A. The Beginnings of Federal Regulation.}

Trading in commodity options has had a centuries-long, turbulent history. ${ }^{11}$ Its first appearance in the United States occurred in the midnineteenth century when options developed as an adjunct to the grain futures markets. Privileges, a form of commodity options, were held in disrepute by everyone except those futures traders who employed them. These options gained an early reputation as gambling contracts, unnecessary to the functioning of the marketplace and used only to place bets on expected price changes.

As early as the 1860s, the directors of the Chicago Board of Trade undertook to regulate the trading of privileges. The directors alternately banned and permitted the practice as internal political battles raged between the floor traders and the officials responsible for the orderly functioning of the futures markets. The directors' attempts at regulation were doomed from the start. The widespread use of privileges among the membership combined with the predisposition of most traders to ignore or resist regulation to make it impossible for the directors to control the practice. ${ }^{12}$ Attempts at self-regulation failed, but the controversy did not end.

In the 1870s, the issue of controlling abuses in option trading eventually found its way to a higher forum. Major political battles raged in the Illinois legislature between anti-option farmers and pro-option traders and businessmen. ${ }^{13}$ Even though the farm bloc was successful in having regulatory laws passed, this attempt at state regulation like-

11. For example, frenzied trading and speculation in tulip futures and options developed in Holland during the 1630s. See A. Reinach, The Nature of Puts and Calls 35-39 (1961). As the speculation pushed the price of tulip bulbs skyward, bulbs were sold on central markets in stock exchanges, and clubs were formed at local taverns to buy and sell them. Rainbolt, Regulating the Grain Gambler and His Successors, 6 Hofstra L. Rev. 1, 5 (1977). Belatedly, the Dutch government attempted to regulate the market, $i d$., but lacking any mechanism such as a clearinghouse or the protection of security deposits to back up the option and futures contracts, the market prices rose out of control and a crash was inevitable. A. REINACH, supra, at 38-39. The regulation did no more than make the process of boom and bust "a bit more orderly." Rainbolt, supra, at 5 . See generally Berger, "Tulipomonia" Was No Dutch Treat to Gambling Burghers, 8 SMITHSONIAN, April, 1977, at 1, 70-76.

12. See generally Lurie 31.

13. M. Powers, Getting Started in Commodity Futures Trading 195 (1977). 
wise proved ineffective-first, because it was difficult to draw a valid distinction between the legitimate and acceptable trading of futures and the unsavory privilege business ${ }^{14}$ and, second, because the laws were generally ignored by grain traders.

Economic developments, which brought reduced prices for farm crops, caused farmers to take their case against options to Congress in the early $1890 \mathrm{~s}^{15}$ Because of their inability to distinguish between the options that farmers sought to ban and the futures contracts that the exchanges fought hard to protect, the legislators several times failed to enact any sort of regulation. But congressional efforts did not end there.

Sentiment against option trading continued to run high, and Congress repeatedly attempted to find some appropriate means of regulation. In the Future Trading Act ${ }^{16}$ of 1921 , Congress attempted to legislate privileges (options) out of existence by imposing a prohibitive tax. ${ }^{17}$ Further congressional efforts to regulate the futures exchanges culminated in the Grain Futures Act ${ }^{18}$ of 1922 - the first comprehensive federal effort to regulate futures trading on the exchanges. This statute required the exchanges and their members to maintain records and to file reports and authorized the Secretary of Agriculture to conduct investigations of exchange operations. While the Act did not speak specifically to commodity option trading, it did require exchanges to prevent price manipulation and the cornering of markets $^{19}$-activities in which option trading could and often did play a role. An exchange that failed to comply with these requirements was subject to suspension or revocation of its contract market designation. ${ }^{20}$ Imposition of this penalty would put the exchange out of business because trading in futures contracts was permitted only on a designated exchange. These restrictions, in combination with the tax, caused options to disappear from the exchanges until the tax was found unconstitutional in $1926 .^{21}$

14. See note 165 infra and accompanying text.

15. Lurie 131.

16. Ch. 86,42 Stat. 187 (1921). Section 3 of this statute was ruled unconstitutional in Trusler v. Crooks, 269 U.S. 475 (1926); section 4 "and the regulations of the act interwoven within it" were earlier declared unconstitutional. Hill v. Wallace, 259 U.S. 44, 72 (1922). Sections 6 and 13 were later repealed. Act of Sept. 6, 1966, Pub. L. No. 89-554, § 8(c), 80 Stat. 645.

17. 1936 Hearings 221 (quoting Future Trading in Grain: Hearings on H.R. 11843 Before the Senate Comm. on Agriculture and Forestry, 67th Cong., 1st Sess. 84 (1921) (statement of Julius H. Barnes)).

18. Ch. 369, 42 Stat. 998 (1922) (current version at 7 U.S.C. $\$ \S 1-22$ (1976)).

19. Grain Futures Act, ch. $369, \S 4$ (d), 42 Stat. 998 (1922).

20. Id. \&6(a).

21. Trusler v. Crooks, 269 U.S. 475 (1926). 
Immediately after the Supreme Court struck down the tax imposed by the Future Trading Act of 1921, privilege trading again became very popular on the Chicago Board of Trade. While no complete statistics were kept, it has been estimated that the volume of trading in privileges in wheat was equivalent to approximately fifteen percent of the volume of trading done in wheat futures on the Chicago Board of Trade. ${ }^{22}$ As with most activity in the Roaring Twenties, option trading was frenetic.

\section{B. The Commodity Exchange Act of 1936.}

The Great Depression brought about renewed suspicion of the exchanges. Speculative short selling in the futures market was blamed for depressed agricultural prices. During July 19 to 20, 1933, the wheat market collapsed, and privilege trading was blamed as the cause. ${ }^{23}$ Spurred on by these developments, Congress once again acted. The resulting Commodity Exchange Act ${ }^{24}$ of 1936 sounded the death knell for option trading. As of June 15, 1936, commodity option trading was banned with respect to all commodities then regulated under the Act. ${ }^{25}$

22. MEHL 101.

23. 1936 Hearings 224. See also 1974 House Hearings 192-93 (statement of Glenn Willett Clark). At the depth of the Depression in 1932, wheat prices reached a 300-year low. Kendall 282. Trading volume on the futures markets diminished to an extremely low level, and the market generally was a place of psychological depression.

Beginning in early 1933, however, the price of wheat began a rapid climb due to a strong new confidence among investors. A number of factors contributed to the surge-traders were inspired by the new administration in Washington, there was a growing fear of inflation and traders generally felt that things could not get much worse. Between January and mid-July of that year, the price of wheat rose from 45 cents to $\$ 1.17$ per bushel. Unfortunately, the euphoria was shortlived. On July 19 and 20, 1933, the price of wheat collapsed, declining 27.5 cents per bushel. See generally Kendall 282.

The Grain Futures Administration (GFA), which was the federal agency created in 1922 to regulate the exchanges, instituted an immediate study to determine the causes of this crash. Its report blamed the activities of ten large traders on the Exchange. GFA ANNUAL REPORT 3 (1934). The Administrator then sought new legislation to supplement the Grain Futures Act which would grant the GFA authority to limit speculative lines, to license merchants and brokers on the exchanges and to take action to prohibit cheating and fraud in the marketplace. In large part, this initiative by the Administrator provided the impetus for the extensive scrutiny of the futures exchanges which resulted in the Commodity Exchange Act of 1936.

According to a report prepared by the Department of Agriculture, the wheat market crash of 1933 "again led the exchanges to seize upon trading in indemnities as one of the evils of future trading that should be abolished." See 1974 House Hearings 192 (statement of Dr. Henry Jarecki). By the time of the 1936 hearings, many of the exchanges had again passed resolutions prohibiting option trading.

24. Ch. 545,49 Stat. 1491 (1936) (current version at 7 U.S.C. $\$ \S 1-22$ (1976)).

25. Commodity Exchange Act, ch. $545, \S 4,49$ Stat. 1491 (1936) (current version at 7 U.S.C. $\S$ 6 (1976)). Interestingly, the legislative history behind the 1936 Act reveals no great controversy or analysis of the effects of option trading on the futures markets. 1974 House Hearings 193 (statement of Dr. Henry Jarecki). In testimony before the Senate Committee on Agriculture and For- 
The 1936 Act divided regulation of the futures markets between the federal government and the exchanges. ${ }^{26}$ Besides the absolute ban on all forms of commodity option trading ${ }^{27}$ in certain enumerated commodities, ${ }^{28}$ the Act provided a system of qualification, registration and recordkeeping for the exchanges and for dealers and brokers operating through those exchanges. ${ }^{29}$ Finally, the Act added criminal sanctions for actual or attempted price manipulation of commodity prices. ${ }^{30}$

With the exception of amendments adding new commodities to the list of those regulated under the original Act, ${ }^{31}$ the Commodity Exchange Act stood virtually undisturbed for over thirty-five years. In the early 1970s, however, a combination of explosive growth in certain unregulated commodity options and drastic developments in world agricultural markets caused Congress to review the federal regulation of commodity futures and option trading. ${ }^{32}$ This review resulted in the Commodity Futures Trading Commission Act of 1974.

\section{The Reemergence of Commodity Option Trading.}

In 1970, a keen interest in commodity options resurfaced. The interest was the result of very active trading in so-called "world commod-

estry, the spokesman for the Department of Agriculture who had only recently authored the comprehensive study of privilege trading on the Chicago Board of Trade made no recommendation regarding the proposed ban on option activity. Rather, he presented an outline of the views that previously had been expressed by the grain exchanges themselves. Instead of making a case to support the ban, he merely pointed out that the grain exchanges all supported the prohibition. 1936 Hearings 219-20.

Perhaps because there was no organized opposition to the ban in 1936, no analysis was made of the economic effects of privilege trading, and no data were presented to support the allegation of abuses in trading the contracts. Privileges and indemnities were merely lumped together in the 1936 Act with "wash sales," "cross trades," "accommodation trades" and other "transactions found to lend themselves to cheating or fraudulent practices." Commodity Exchange Act, ch. 545, sec. 5, § 4c, 49 Stat. 1491 (1936) (current version at 7 U.S.C. § 6c (1976)).

26. Indeed, one commentator has characterized the system of regulation established by the 1936 Act as one of "strong exchange self-regulation with weak federal oversight." Rainbolt, supra note 11 , at 11 (emphasis in original).

27. Commodity Exchange Act, ch. 545, sec. 5, § 4c(B), 49 Stat. 1491 (1936).

28. Commodity Exchange Act, ch. $545, \S 3(\mathrm{a}), 49$ Stat. 1491 (1936) ("The word 'commodity' shall mean wheat, cotton, rice, corn, oats, barley, rye, flaxseed, grain sorghums, mill feeds, butter, eggs and Solanum tuberosum (Irish potatoes)").

29. Commodity Exchange Act, ch. 545, $\S 5$, 49 Stat. 1491 (1936).

30. Commodity Exchange Act, ch. 545, \& 9, 49 Stat. 1491 (1936).

31. Wool tops were added in 1938, Act of April 7, 1938, ch. 108, 52 Stat. 205; fats, oils, cottonseed meal, cottonseed, peanuts, soybeans and soybean meal were added in 1940, Act of Oct. 9, 1940, ch. 786, 54 Stat. 1059; and livestock, livestock products, Act of Feb. 19, 1968, Pub. L. No. 90-258, 82 Stat. 26, and frozen concentrated orange juice, Act of July 23, 1968, Pub. L. No. 90-418, 82 Stat. 413 were added in 1968. Trading in onion futures was prohibited in 1958, Act of Aug. 28, 1958, Pub. L. No. 85-839, 72 Stat. 1013.

32. See text accompanying notes 63-68 infra. 
ities"-for example, silver, platinum, copper, coffee, cocoa and sugar-that began to attract the attention of a number of American firms interested in fashioning new investment possibilities in those commodities. The American firms quickly discovered that there was a gap in the coverage of the Commodity Exchange Act ban on options. Since the Act governed only certain enumerated domestic commodities, ${ }^{33}$ it did not prohibit the sale of options in the "world commodities." 34 Spurred on by the sudden volatility of prices in the London commodities, a new industry quickly emerged in the United States to offer options on those commodities to the American public. This renewed activity employed three different hybrids of the well-known commodity option: London options, naked options and dealer or Mocatta options.

1. London Options. The first type of option to evolve outside the scope of the 1936 Act was the so-called "London option." While this term has been used recently in something of a generic sense, the term actually refers to those options traded on the seven major exchanges in London. ${ }^{35}$

Trading in options on the London exchanges has been conducted

33. See notes 28 \& 31 supra.

34. For examples of "world commodities," see note 35 infra.

35. Five of these exchanges handle what are often collectively referred to as the "soft commodities": wool, cocoa, sugar, coffee and vegetable oil. Futures and option transactions on these exchanges are cleared by a common clearinghouse, known as the International Commodity Clearing House $(\mathrm{ICCH})$, which is an independent, privately owned subsidiary of the United Dominion Trust, an English banking group.

Trading on the five exchanges in the $\mathrm{ICCH}$ group is conducted by public auction among the trading members of each exchange. Once the terms of an option contract have been established on the floor of the exchange, the exchange obtains a verification from both parties to the trade and forwards a record of the transaction to the $\mathrm{ICCH}$ for clearing. The clearinghouse then collects a margin deposit from the grantor of the option to insure performance by the grantor if the option is exercised. The clearinghouse also collects and holds the premium paid by the purchaser. The premium is held in a special account and is not released to the grantor until the option expires, is exercised or is abandoned by the holder. The ICCH actually becomes a party to the transaction, issuing a "seller's contract" to the grantor of the option and a "taker's contract" to the purchaser of the option. By these means, the clearinghouse itself takes responsibility for performance by both parties. This obligation of the London clearinghouse (often referred to as the clearinghouse "guaranty") is backed by ICCH capitalization which consists of approximately $\$ 8.5$ million in assets.

The conduct of option trading is very different on two other major London exchanges. In the case of the London Rubber Exchange, trading is conducted by private negotiations among member brokers. This exchange has been described as little more than a meeting place where exchange members can negotiate their trades. It does maintain a settlement house, but it is operated in a different manner from that of the ICCH. The settlement house registers contracts negotiated between two of its members without becoming a party to the transaction. All option contracts are issued directly by a grantor to the taker. There is no clearinghouse "guaranty" of any of the contracts, and the premium paid by a purchaser is immediately turned over to the grantor. There 
for decades by respectable, financially sound firms. Prior to 1970 , most of the option trading on the London exchanges was done by commercial interests that utilized options to lock in a price for future production or to guard against increases in the cost of anticipated needs for a particular commodity. ${ }^{36}$ The integrity of most London options is backed by clearinghouse guaranties or, in the case of the London Metal Exchange, by the financial strength of the ring-dealing members who issue the contracts. Thus, by giving options the same respectability as futures contracts and by providing the same safeguards available for futures contracts, the London exchanges have been able to make options available to investors without any major difficulties.

Although option trading proceeded without difficulty on the London exchanges, the image of London options was tarnished by the manner in which they were marketed in this country prior to the 1978 ban on trading. ${ }^{37}$ Since the London exchange members did not have offices in the United States to sell options, American option purchasers were forced to deal with an American brokerage firm. Upon receipt of a customer order, such a firm would contact a member of the appropriate London exchange for the purpose of purchasing an option. That exchange member would then enter into the option contract with another member of his exchange. ${ }^{38}$ In most cases, the exchange would require the posting of a margin deposit by the grantor and would hold the purchaser's premium. ${ }^{39}$

The problem for the American customer in these transactions was that the protection of clearinghouse guaranties, together with any margin deposits and segregated premiums, extended only to the exchange member in London and not to the American customer. In the event of a default on the option contract, the customer's only recourse was

is a requirement, however, that the grantor post margin deposits to insure performance in the event of an exercise of the option.

Finally, on the London Metal Exchange (LME), option trading is conducted in an open auction market on the floor of the exchange. The only firms allowed on the trading floor are the thirty-six firms known as "ring dealers." Other firms who are members of the exchange must conduct all of their trading through one of these thirty-six ring dealers. The LME does allow "offexchange" trading, and much of the option trading is conducted in this manner, with the parties privately negotiating the premium to be paid. The exchange does not maintain a settlement or clearinghouse and does not itself register or issue option contracts. Trading on the LME does not carry with it any guaranty of performance, and no margin requirements are imposed on option grantors. The exchange encourages its members to require margin deposits and to escrow premiums, but there is no requirement that these procedures be followed. See generally Long 111-24.

36. See 1974 House Hearings 179 (statement of Maurice Stockdale).

37. See text accompanying notes 83-97 infra.

38. Long 124.

39. Both grantor margins and the holding of premiums are required only in the case of ICCH-cleared option transactions. Id. 113. See note 35 supra. 
against the American firm with which he had dealt. Moreover, the American customer paid an amount greater than the premium required to purchase the option in London. In addition to the premium, he also paid commissions, directly or indirectly, to the American broker and to the London broker. In many cases there might have been additional brokers in the chain between the customer and the exchange member who actually bought his option on the London exchange. ${ }^{40}$

It is more accurate to say that what the American customer purchased from his broker was not a London option, but an obligation from the American firm to enter into a contract on the customer's behalf with another broker who was a member of the London exchange, who in turn agreed to enter into an option transaction for the account of the American broker. The London exchange member did not have any record of the particular customer involved, and the customer was not an actual party to the option contract. Thus, the United States customer had only a contractual obligation from his broker to pay the customer a certain amount of money if the market moved in his favor.

[I]n a very real sense the brokerage client is making an investment in the general assets of the broker with the expectation that the broker will use that money in such a way as to generate sufficient income so that he will be able to pay the client his profit as determined by an independent factor, the London market, upon exercise of his option. ${ }^{41}$

The difficulty with this situation for the customer was that he had no way of knowing whether his option had actually been purchased by his broker. Even if his option had been obtained and the market had moved in his favor, he was forced to rely upon the solvency of his broker for payment of any gain. If his broker went bankrupt, the customer had no means of recovering from the margin deposits or segregated premiums in London, except as a general creditor of the broker. Thus, when dealing in such options, the customer/optionee faced substantial risks-especially in light of the fact that his brokers were free of all regulation. ${ }^{42}$

2. Naked Options. Another type of "commodity option" that emerged in the early 1970 s was the "naked" option. Beginning in 1971, the firm of Goldstein-Samuelson, Inc. began marketing what it called

40. Moreover, some dealers took unfair advantage of unsophisticated investors by charging excessive markups. For example, reports indicated that Lloyd Carr \& Co. was selling an option for $\$ 6,360.00$ when other dealers were offering it for only $\$ 1,800.00$. Wall St. J., Feb. 14, 1978, at 41, col. 1 .

41. Long 127.

42. See text accompanying notes 33-34 supra. 
commodity options to the public. Implementing sales techniques masterminded by Harold Goldstein, the firm promoted the sale of these options with extensive advertising and hard-sell or "boiler room" tactics. ${ }^{43}$ Starting with an initial capitalization of $\$ 800$ in 1971 , the firm exploded into a network of offices throughout the United States and abroad with gross income by the end of 1972 estimated at $\$ 45$ million. ${ }^{44}$ Spurred on by this success, dozens of other firms appeared virtually overnight to help reap the bounty. It is estimated that "commodity option" sales had become a $\$ 200$ to $\$ 300$ million per year industry by February $1973 .{ }^{45}$

While London options had been available in the United States through the older, established commodity brokers prior to that time, Goldstein was the first to begin selling options with mass marketing techniques. Those efforts were directed at small, unsophisticated investors who knew little or nothing about the commodity markets and the complex futures trading industry.

Unlike transactions in London options, where a member of one of the London exchanges actually obtains an option contract and "sells" it through a series of brokers, the naked option involved no connection with the London exchanges. While the customer was led to believe that he was purchasing a London option, the contract was never obtained ${ }^{46}$ Thus, in reality, the customer purchased merely a promise by the firm to pay a sum of money determined by price movements on the appropriate London exchange. Such options are considered "naked" in the sense that they were not backed by an actual futures contract or physical inventory held by a member of an exchange, and no margin deposits or segregated premiums were available to insure payment of any gain to the customer. ${ }^{47}$

Goldstein-Samuelson claimed that it was hedging its option obligations in the market by purchasing futures contracts for the firm account. However, rather than obtaining a futures contract for each option sold, they likened their hedging to the cash reserve maintained by a bank or insurance company on the theory that only a certain per-

43. The term "boiler room" has been used to describe offices that set up large banks of telephones from which option salesmen made thousands of unsolicited, high-pressure telephone calls to unsophisticated members of the general public. See Complaint at 4-5, CFTC v. Carr, Civ. No. G77-550CA5 (W.D. Mich. 1977).

44. Note, Federal Legislation for Commodity Option Trading: A Proposal, 47 S. CAL. L. REv. 1418,1426 (1974).

45. $I d$.

46. See Long, The Naked Commodity Option Contract as a Security, 15 WM. \& MARY L. Rev. 211, 211-12 (1973).

47. $I d$. 
centage of contracts would result in payments being owed to customers. ${ }^{48}$ However, the fact was that no hedging was actually undertaken, and the obligation to pay customers was supported solely by the inadequate capitalization of the company plus the cash flow generated by further option sales to other customers. The arrangement was reminiscent of the "bucket shops" of an earlier age wherein commodity brokers merely took the other side of a transaction from their customers and, in effect, wagered that the market prices would move in their favor. ${ }^{49}$ It was destined to fail because, as in other "pyramid" schemes, an ever-increasing number of customer sales was necessary to keep the business operating for any length of time.

During the initial stages of the bullish commodity markets of the early 1970 s, the company was able to maintain an extremely rapid expansion of sales. However, price increases in commodities such as coffee and sugar in 1970 were so dramatic and resulted in such large gains for option customers that the firm was soon unable to pay. Without actual hedged positions in the marketplace, it had no means by which to deliver the appropriate futures contracts to its customers or otherwise to realize the gains accruing to the supposed "option" positions. ${ }^{50}$

In early 1973, Goldstein-Samuelson and two other large option firms were put into involuntary receivership by the California Corporations Commissioner, who banned further option sales. ${ }^{51}$ On April 30, 1973 , after being investigated in a number of states, Goldstein-Samuelson was declared bankrupt. ${ }^{52}$ It has been estimated that the GoldsteinSamuelson firm left behind as much as $\$ 85$ million in unsatisfied claims of "commodity option" purchasers. ${ }^{53}$

From a regulatory point of view, the naked option scheme presented serious difficulties. Since firms such as Goldstein-Samuelson dealt in commodities not expressly enumerated by the Commodity Ex-

48. Long $85-86$.

49. Wall St. J., June 28, 1973, at 38, col. 1. In 1920, Charles Bianci, alias Charles Ponzi, set up shop near Boston's city hall. He promised investors he would double their money in 90 days and actually did so for his initial customers. As might be expected, word of this amazing offer spread like wildfire. People lined the street in front of Ponzi's office to turn over their money. Ponzi took over $\$ 10$ million before he was exposed. His simple scheme consisted of paying off old customers' profits with new customers' incoming cash and relying upon exploding growth to sustain the operation. Id. See also Ferris, Justice Holmes and the Bucketshops, FARM Q.,Winter 19681969 , at 6 . (1975).

50. Comment, Regulation of Commodity Related Abuses, 22 WAYNE L. REv. 137, $156 \mathrm{n} .93$

51. In re Goldstein-Samuelson, Inc., No. 7303131 (C.D. Cal. Mar. 29, 1973).

52. Stipulation of All Relevant Facts in Lieu of Trial on Preliminary and Permanent Injunction for the Plaintiff at 3-7, SEC v. Goldstein-Samuelson, Inc., No. 73-472 RJK (C.D. Cal. Oct. 11, 1973).

53. Long 83 n.29. 
change Act of $1936,{ }^{54}$ there existed neither authority nor mandate to regulate these option firms. ${ }^{55}$

It should be clear that the Goldstein-Samuelson commodity option business really had nothing whatsoever to do with commodity options. ${ }^{56}$ A customer of Goldstein-Samuelson never acquired any interest either directly or indirectly in an option contract. Rather, he was in effect buying a stake in the assets of Goldstein-Samuelson, Inc. and was relying upon that firm's "expertise" in the option markets, or at least its ability to continue generating "option" sales." Nonetheless, this activity became identified with commodity options and futures markets and has tended to obfuscate an objective consideration of true commodity options.

3. Dealer Options. The great public fascination with commodity options that characterized the early 1970 s brought success to yet another type of commodity option: the Mocatta or dealer option. Unlike the London option, such options are granted by a company that deals in the actual commodity, usually gold or silver bullion. These options are neither traded on an exchange nor processed by a clearinghouse. ${ }^{58}$ Rather, they are issued directly by a dealer in the physical commodity to the option purchaser or to a broker who will market the

54. See notes 28 \& 31 supra.

55. Because of the massive defaults that resulted, however, a number of state securities commissioners took enforcement action and eventually managed to put a number of firms out of business. See, e.g., In re Goldstein, Samuelson, Inc., [1971-1978 Transfer Binder] BLUE SKY L. REP. (CCH) I 71,095 (Okla. Dep't Sec. 1973). The termination of the Goldstein-Samuelson operation was triggered by an enforcement action instigated by the Oklahoma Department of Securities. In February 1973, that Department obtained a cease and desist order against the firm barring any further sales of naked options in Oklahoma. Shortly thereafter, a number of other state securities administrators began to take action against the sale of naked options. Naked options were deemed to be securities under the securities laws of the various states, either on the theory that they constituted "investment contracts" or that they were "evidences of indebtedness" or "instruments commonly known as securities." Long 88-102.

56. Comment, supra note 50 , at 156 n.93. Indeed, the consensus appears to be that naked options possess no economic utility whatever and should not be considered commodity options. The only connection between a "naked" option and the commodity futures markets is the fact that the market prices of futures are used as an index to determine which options are "in the money." As one commentator has stated, the naked option dealers could just as easily have wagered "on the temperature in Los Angeles or the whereabouts of Secretary Kissinger." 1974 House Hearings 194 (statement of Dr. Henry Jarecki). The only economic effect that has been attributed to naked option trading is that it probably drains liquidity from the legitimate futures markets by luring away speculators. 1974 Senate Hearings 829.

57. Compare the operation of the "Ponzi" scheme, discussed at note 49 supra.

58. The information included here about Mocatta Metals Corporation is taken from the company's request for a "no-action" letter regarding the company's sale of options and from the Securities and Exchange Commission's reply. The correspondence is collected at [1974-1975 Transfer Binder] FED. SEC. L. REP. (CCH) I 79,940. 
contracts. These options are often issued against inventories of the physical commodity or against futures contracts in the commodity, ${ }^{59}$ but there is generally no requirement that they be so backed or hedged.

The major regulatory concern over dealer options has been that they are not necessarily limited to contracts backed by a sufficient amount of the physical commodity to insure performance of the option commitments. Thus, similar to London and to naked options, a purchaser of dealer options undertakes two separate types of risk: the risk of price fluctuation in the underlying commodity and the risk that the grantor will be unable to perform its obligations. ${ }^{60}$ The latter type of risk has prompted the Georgia Securities Commissioner to take the position that the sale of a futures contract or option wherein the seller of the contract does not possess the necessary physical commodity to fulfill his obligations constitutes an investment contract under Georgia securities law. ${ }^{61}$

The view of the Georgia Commissioner is based upon the notion that securities law registration provisions are intended to provide information to the investor sufficient to help him analyze the degree of risk that he is undertaking in dealing with a particular issuer. With dealer options, to the extent that such options are not backed by the physical commodity, there is an "enterprise risk"- the financial stability of the granting firm-separate from the risk presented by price fluctuations for the underlying commodity ${ }^{62}$ While dealing in Mocatta options was not fraught with the abuses that were the apparent concomitants of London and naked options, this risk to consumers alone was sufficient to bring Mocatta dealings into the limelight when Congress in 1973 finally began to review the state of affairs in the option and futures markets.

\section{The Commodity Futures Trading Commission Act of 1974.}

In certain respects, regulation of the London, naked and Mocatta options sold in the United States in the 1970s suffered from deficiencies similar to those present in efforts to regulate the troublesome privileges of the nineteenth century. ${ }^{63}$ The sales occurred off the exchanges, with-

59. See the description of dealer options presented by Mocatta Metals Corp. to the SEC in which they explained that in their operation Mocatta would either own the necessary silver bullion to meet its option commitments or, in the alternative, would have the capacity to acquire a sufficient quantity to do so. Mocatta Metals Corp., No-Action Letter (July 1, 1974), reprinted in [1974-1975 Transfer Binder] FED. SEC. L. REP. (CCH) I 79,940, at 84,425.

60. Long 109-10.

61. Georgia Sec. Comm'r Rel. No. 1, 1A Blue SKy L. REP. (CCH) q 14,612 (Sept. 18, 1973).

62. Id.

63. See text accompanying notes 11-12 supra. 
out the protection of any clearinghouse guaranties or deposits. Since they were virtually unregulated, these transactions were easily subject to fraud and abuse and provided extreme risks for the consumer/investors involved. Due to their apparent lucrativeness and their unregulated nature, sales in these types of options burgeoned. ${ }^{64}$

Paralleling this tremendous growth in option and futures trading were several agricultural developments that wreaked havoc on world food prices. ${ }^{65}$ A reduction of government reserves of feed grain pursuant to a policy of freer agricultural markets, the mysterious disappearance of anchovies off the coast of Peru (anchovies being a major source of protein) and a sharp reduction in supplies of peanut meal (the world's third major source of feed) due to a terrible drought in India and parts of Africa ${ }^{66}$ combined to produce spiraling food prices. This phenomenon renewed the century-old suspicion that backroom speculators were once again manipulating prices. ${ }^{67}$

These parallel-and related-developments of exponentially expanding trading and disastrous agricultural developments coincided to produce strong pressure on Congress to reexamine the commodity futures markets. ${ }^{68}$ The Commodity Futures Trading Commission Act of $1974^{69}$ was the result.

For instance, because it was considered akin to gambling, trading in privileges was not permitted in the pits of the Chicago Board of Trade futures exchange and was denied the enforcement and protective mechanisms of the Exchange, see note 7 supra, but was not banned outright. Consequently, trading in privileges remained "a widely accepted business practice," Lurie 32, over which no effective regulation could be asserted. The volume of trade increased erratically in the 1870 s, leading to an increase in natural price fluctuation. This encouraged speculators to "run corners." Id. 39. To the extent that privileges were used to corner the market, the Board abdicated its ability to control the abuse by moving option trading from the floor to the backroom. The lack of regulation led, in part, to the abuses.

64. H.R. REP. No. 975, 93d Cong., 2d Sess. 41 (1974). This increase in option sales parallels an explosive growth in commodity trading generally. Between 1969 and 1973, the volume of trading on the regulated commodity exchanges nearly doubled from 9.3 to 18.2 million contracts. During the same period, futures in unregulated commodities-such as cocoa, coffee, sugar, precious metals, wood products and foreign currency-quadrupled from 1.8 million to 7.5 million contracts. See text accompanying notes 32-34 supra.

65. Small Business Problems Involved in the Marketing of Grain and other Commodities: Hearings Before the Subcomm. on Special Small Business Problems of the House Permanent Select Comm. on Small Business, 93d Cong., 1st Sess. 135 (1973) (testimony of Frederick Uhlmann).

The economic developments included what the Chairman of the Chicago Board of Trade has referred to as an "extraordinary coincidence of global events which suddenly wiped out the last of our dwindling grain surpluses and plunged the world into severe shortages of food." Id.

66. Greenstone, The CFTC and Government Reorganization: Preserving Regulatory Independence, 33 Bus. LAw. 163, 164, 180 (1977).

67. See note 23 supra and accompanying text.

68. See 120 Cong. REC. 10738-39 (1974) (remarks of Rep. Mayne).

69. 7 U.S.C. $\$ \S 1-22$ (1976). 
The 1974 Act constituted a substantial revision of the 1936 Act. $^{70}$ In it Congress extended the coverage of the Commodity Exchange Act to include not only previously unregulated commodities, but also all other goods, articles, and all services, rights and interests in which futures contracts might be traded. ${ }^{71}$ In addition, the 1974 Act created the CFTC, giving it the status of an independent agency to administer the Commodity Exchange Act. ${ }^{72}$ The Commission was granted exclusive jurisdiction over transactions involving futures contracts and certain other commodity-related activities, including option trading. ${ }^{73}$

With respect to commodity options, the CFTC Act continued the prohibition on option transactions involving the agricultural commodities enumerated prior to 1974. However, Congress gave the Commission the power to extend this prohibition to options on any other commodities covered under the new Act or to permit options on previously nonenumerated commodities to be traded subject to whatever terms and conditions the Commission might prescribe. ${ }^{74}$ Thus, for the first time, commodity options became subject to regulation by a federal agency. ${ }^{75}$

\section{CFTC ACrIvity SINCE 1974}

In 1974 Congress clearly expected that the newly created independent Commission would be capable of regulating those firms engaged in selling commodity options so that episodes like the GoldsteinSamuelson affair would not recur. ${ }^{76}$ Initially, the CFTC was given one year in which to promulgate rules and regulations to govern option

70. For a detailed discussion of the major provisions of the CFTC Act, see Purcell \& Valdez, The Commodity Futures Trading Commission Act of 1974: Regulatory Legislation for Commodity Futures Trading in a Market-Oriented Economy, 21 S. DAKoTA L. REv. 555, 565-90 (1976).

71. 7 U.S.C. $\$ 2$ (1976).

72. Id. $\$ 4 \mathrm{a}(\mathrm{a})$.

73. Id. § 2. This section provides in pertinent part:

That the Commission shall have exclusive jurisdiction with respect to accounts, agreements (including any transaction which is of the character of, or is commonly known to the trade as, an "option", "privilege", "indemnity", "bid", "offer", "put", "call", "advance guaranty", or "decline guaranty"), and transactions involving contracts of sale of a commodity for future delivery, traded or executed on a contract market designated pursuant to . . . this title or any other board of trade, exchange, or market . . . .

74. $I d . \$ 6 \mathrm{c}$.

75. Specifically, section 6c(b) of the CFTC Act provides:

No person shall offer to enter into, enter into, or confirm the execution of, any transaction . . . involving any commodity ... not specifically set forth in section 2 of this title ... which is of the character of, or is commonly known to the trade as, an 'option' . . . contrary to any rule, regulation, or order of the Commission prohibiting any such transaction or allowing any such transaction under such terms and conditions as the Commission shall prescribe....

76. In the 1974 legislation, Congress demonstrated its faith in the CFTC by giving it virtually complete authority over option trading on the previously unregulated commodities-allowing the 
trading. ${ }^{77}$ However, this period was extended at the request of the Commission to allow the formulation of a comprehensive set of rules to govern this activity. ${ }^{78}$ Because the project proved too ambitious, the Commission chose to adopt interim rules to govern off-exchange commodity option trading before undertaking the more difficult task of fashioning regulations for trading on the domestic exchanges. ${ }^{79}$

The interim or "Part A" regulations, adopted November 24, 1976, set forth a number of requirements for firms and individuals involved in option trading. As of January 17, 1977, firms offering options to the public were required to register with the Commission as futures commission merchants (FCMs). Similarly, individuals engaged in soliciting orders from customers were required to register as "associated persons." ${ }^{\circ 0}$ As FCMs, the firms became subject to minimum financial requirements set forth in the Commission's regulations. ${ }^{81}$ In addition, a number of customer protection rules were set forth, including the required segregation of customer funds, disclosures of risk to customers and recordkeeping. ${ }^{82}$

By mid-summer 1977, the Commission had licensed sixty American firms to conduct business in London options under the interim regulations. ${ }^{83}$ However, the task of eliminating abuses in the sale of such options proved more burdensome than had been anticipated. Indeed, rather than diminishing under Commission regulation, the problems and abuses that had plagued commodity options in the early 1970s increased drastically. ${ }^{84}$ Perhaps encouraged by the official recognition of London option trading, many new firms, employing rather questionable practices, entered the business during 1976 and 1977. Throughout the months of December 1977 and January 1978, American newspapers were filled with stories of commodity option fraud perpetrated by firms like Lloyd Carr \& $\mathrm{Co}^{85}$

CFTC either to ban such trading altogether or to regulate it in any manner the CFTC might choose. See 1978 House Appropriation Hearings 628-31.

77. 7 U.S.C. \& 6c(b) (1976).

78. See 41 Fed. Reg. 16,685 (1976).

79. Id. 51,808-17. See also 1978 House Hearings 37-38 (statement of William Bagley).

80. 17 C.F.R. § 32.3 (1977).

81. Id. $\S 1.17$.

82. Id. $\$ \S 32.5-9$.

83. CFTC News Release \#316-77, July 27, 1977, at 3.

84. 1978 House Appropriation Hearings 28.

85. See, eg., Carr Suspect Believed to Shift Funds, Washington Post, Jan. 30, 1978, § D, at 7, col. 1; Four Firms Accused of Trading Violations with London Options, Wall St. J., Jan. 27, 1978, at 21, col. 1; Kramer, Options Man Caught in \$130-a-Day Fla. Suite, Washington Post, Jan. 26, 1978, $\S \mathrm{D}$, at 9, col. 1; Three Officials Are Arrested in Commodities Options Case, Washington Post, Jan. 11, 1978, \& D, at 1, col. 1; Lynch, Lloyd Carr Case Seen Testing CFTC/As Firm Grows Despite Legal Hassles, Wall St. J., Dec. 21, 1977, at 22, col. 4.

Goldstein-Samuelson's mass-marketing success was repeated five years later by Lloyd Carr \& 
While accurate figures are not available, this recent wave of activity in the commodity option area has involved several hundreds of millions of dollars invested by unsophisticated investors through several dozen firms. ${ }^{86}$ Despite the extensive authority and powers given to the CFTC in 1974 to deal with deceptive sales practices and fraudulent transactions attributed to firms like Lloyd Carr, commodity option sales presented a regulatory problem of major proportions for the CFTC. ${ }^{87}$ Although the Commission managed to obtain injunctions against fifty-five commodity option firms and individuals and takes credit for putting fourteen companies out of business, ${ }^{88}$ it approached 1978 congressional oversight hearings ${ }^{89}$ with a dismal record for protecting the public. Quite simply, the commodity option industry had grown to a size that the fledgling Commission could not control.

Co., Ltd. Lloyd Cars was formed with an initial capitalization of $\$ 2,000$ in mid-1976. In the space of 18 months, it had mushroomed into a major enterprise with 12 commodity option sales offices across the country operated by over 700 employees. Lynch, supra. By the time an injunction was issued against the firm in Michigan in December 1977, Kelley v. Carr, 442 F. Supp. 346 (W.D. Mich. 1977), sales had ballooned to an estimated annual rate of more than $\$ 50$ million. Lynch, supra. For the administrative proceedings before the CFTC involving Lloyd Carr, see In re Carr, CFTC Docket No. 77-6, CoMm. Fut. L. REP. (CCH) If 20,454 (1977), remanded with directions, Lloyd Carr \& Co. v. CFTC, 567 F.2d 1193 (2d Cir. 1977).

The Lloyd Carr situation was, in fact, the most notorious failure of the Commission in controlling commodity option fraud. The Commission began on February 8, 1977 to seek injunctive relief in the United States District Court for the District of Massachusetts since the firm had not registered to sell commodity options under the interim regulations. The District Court Judge twice denied the Commission's motion for a temporary restraining order and refused to rule on the Commission's motion for a preliminary injunction. This decision was appealed to the First Circuit Court of Appeals and resulted in a remand to the District Court for further appropriate action. Kelley v. Carr, Comm. Fut. L. Rep. (CCH) I 20,510 (W.D. Mich. 1977).

On November 3, 1977, the Commission filed a motion in the United States District Court for the Western District of Michigan seeking similar relief against the Lloyd Carr firm. On November 14, Chief Judge Fox entered a temporary restraining order against the firm and the individual defendants enjoining them from further violations of the Commission's anti-fraud regulations and other provisions of the Commodity Exchange Act. Id.; Kelley v. Carr, 442 F. Supp. 346, 348, 359 (W.D. Mich. 1977). On January 9, 1978, Judge Fox also issued a writ of arrest pursuant to which James Carr and others were arrested by the U.S. Marshals in Boston. Kelley v. Carr, CoMm. FuT. L. REP. (CCH) I 20,510 (W.D. Mich. 1977). In the course of the investigation conducted thereafter by the Federal Bureau of Investigation, it was discovered that James Carr was in reality Alan Abrahams, an escaped convict from New Jersey. Carr Suspect Believed to Shift Funds, supra.

86. Then CFTC Vice-Chairman John V. Rainbolt II estimated in January 1978 that the volume of London option sales amounted to at least $\$ 200$ to $\$ 300$ million annually, or about two percent of the $\$ 1$ trillion-plus total volume in futures trading in the United States in 1977. Washington Post, Jan. 7, 1978, § C, at 8, col. 5.

87. By the end of fiscal year 1977 , the Commission estimated that $20 \%$ of its total staff was involved in regulating commodity option sales. In fiscal year 1977 alone, the CFTC spent $\$ 1.5$ million and 50 staff-years attempting to control the problems connected with commodity options. 1978 House Appropriation Hearings 29.

88. Id.

89. Section 101(b) of the CFTC Act of 1974, 7 U.S.C. $\$ 16(d)$ (1976), had authorized appropriations of funds to carry out the provisions of the Act for four fiscal years ending June 30, 1978. 
At the Commission meeting held on January 25, 1978, Chairman Bagley announced publicly that the CFTC had been unable to regulate the sale of London options to the public. ${ }^{90}$ The Commission attributed its failure to control firms such as Lloyd Carr in part to the absence of a body of appellate law interpreting the 1974 Act, which would have expedited the securing of injunctive relief. ${ }^{91}$ Moreover, the Commission claimed it lacked sufficient financial resources to police the options area effectively. ${ }^{92}$ For these reasons, the Commission voted to publish a proposal for the suspension of all London and dealer option transactions. ${ }^{93}$ Notice of the proposed suspension was published in the Federal Register on February 6, 1978,94 and after public hearings, a notice of suspension was published on April 17, 1978. ${ }^{95}$ The suspension, with only limited exemptions for trade options ${ }^{96}$ and a limited class of dealer options, became effective on June 1, 1978. ${ }^{97}$

With the Commission's suspension action as a backdrop, both the Senate Committee on Agriculture, Nutrition and Forestry and the House Committee on Agriculture, in connection with their respective reauthorization hearings, began to review the performance of the CFTC.98 Due to the widely publicized scandals in commodity option sales, each committee spent a great deal of time examining the commodity option industry. In response to these scandals, a bill was introduced in the House that would have imposed a permanent ban on all commodity option trading.9 ${ }^{99}$ The Senate's response, S. 2391, also proscribed all commodity option trading, but, unlike the House version, the proposed Senate ban was to remain in effect until further action of

90. CFTC Proposes London Options Sales Suspension, Washington Post, Jan. 26, 1978, \& D, at 11, col. 1 .

91. 1978 House Appropriation Hearings 143. See note 76 supra.

92. 1978 House Appropriation Hearings 34-35.

93. Id. 452.

94. 43 Fed. Reg. 4,869 (1978) (to be codified in 17 C.F.R. Part 32).

95. 43 Fed Reg. 16,153 (1978) (to be codified in 17 C.F.R. $\$ 32.11$ )

96. Trade options are used by commercial interests in their dealings with similar commercial interests and do not involve consumers. 43 Fed. Reg. 16, 153 (1978) (to be codified in 17 C.F.R. $\$$ 32.11).

97. Id. There do exist, however, provisions for lifting the suspension. In determining when and whether the suspension will be lifted, the Commission will consider (1) the prospects for effective self-regulation, (2) the success of a pilot program for domestically exchange-traded options, (3) whether customers can be protected if foreign options are included in the pilot program and (4) the strengthening of the CFTC's enforcement capability. 43 Fed. Reg. 16,160 (1978).

98. See S. REP. No. 850, 95th Cong., 2d Sess. 13 (1978); H. REP. No. 1181, 95th Cong., 2d Sess. 10-12 (1978)

99. H.R. 10901, 95th Cong., 2d Sess., 124 CoNG. REC. H944 (daily ed. Feb. 9, 1978) (introduced by Rep. Smith of Iowa). 
the Commission. ${ }^{100}$

Witnesses testifying before the Subcommittee on Conservation and Credit of the House Committee on Agriculture were split almost evenly on the question of whether option sales should be banned or permitted. ${ }^{101}$ The House Committee voted to include the ban in the final version of H.R. 10285, reporting the bill out with the following explanation:

The Committee recognizes the magnitude of the abuses which have been perpetrated on the public in the offer and sale of commodity options and believes that the Commission should have a period of time in which to evaluate fully the terms and conditions under which commodity options might be offered, if at all, consistent with adequate customer protection. Accordingly, H.R. 10285 imposes a Congressional ban on all commodity option transactions involving those commodities not set forth in section 2(a)(1) of the Act unless such transactions are expressly permitted under rules and regulations adopted by the Commission subsequent to the date of enactment of the bill. ${ }^{102}$

The House bill effectively affirmed the action taken by the Commission in banning commodity option sales and gave the Commission the authority to formulate a new program to regulate such trading, subject to a congressional veto. ${ }^{103}$ The Senate Committee, on the other hand, approved a ban on commodity option trading, but did not give the Commission authority to grant exemptions from that ban except via a program for domestic exchange trading. ${ }^{104}$

The conference committee adopted a compromise version of the ban on option trading that carried forward the ban on all offers and sales of commodity options, with the exception of trade options and certain dealer options. ${ }^{105}$ The Commission would be allowed, how-

100. S. 2391, 95th Cong., 2d Sess., 124 CoNG. REC. S28 (daily ed. Jan. 19, 1978) (introduced by Sen. Huddleston).

101. H.R. Rep. No. 1181, 95th Cong., 2d Sess. 34 (1978).

102. Id, 17 .

103. H.R. 10285, as passed by the House on July 26, 1978, provided in section 2 that any subsequent rule or regulation allowing option trading could not become effective until 10 days after it was submitted to the House and Senate Agriculture Committees and neither House of Congress passed a resolution disapproving the rule within that time. $I d .26$.

104. S. 239l, 95th Cong., 2d Sess. $\$ 2$ (1978) (as adopted by the Senate on July 12, 1978).

105. S. Rep. No. 1239, 95th Cong., 2d Sess. 19 (1978). Exempted from the ban are "trade" options. Futures Trading Act of 1978 , Pub. L. No. $95-405$, sec. 3(3), $\S 4 \mathrm{c}(\mathrm{c}$ ), 92 Stat. 865 (to be codified in 7 U.S.C. $\$ 6 \mathrm{c}(\mathrm{c})$ ). The Act exempts a narrow class of dealers granting options to the general public:

Notwithstanding the provisions of subsection (c) of this section-

(1) any person domiciled in the United States who on May 1, 1978, was in the business of granting an option on a physical commodity and was in the business of buying, selling, producing, or otherwise using that commodity, may continue to grant or issue options on that commodity in accordance with Commission regulations in effect on 
ever, to come forward with a new plan of regulation and evidence of its ability to regulate options effectively, in which case the ban would be lifted. ${ }^{106}$ The bill, now known as the Futures Trading Act of 1978, became law on September 30, 1978. ${ }^{107}$

Regardless of the contours of the commodity option program, it is abundantly clear that neither the CFTC nor Congress will accede to permanent trading unless it can be shown that such trading will further some economic purpose or will benefit the public. ${ }^{108}$ While some would disagree, ${ }^{109}$ this author feels that there are substantial economic benefits to be realized in a properly regulated option market. Any assessment of the outcome of the test of regulated trading embodied in the pilot program requires a proper understanding of the potential benefits of option trading.

August 17, 1978, until thirty days after the effective date of regulations issued by the Commission under section (2) of this subsection ...

(2) the Commission shall issue regulations that permit grantors and futures commission merchants to offer to enter into, enter into, or confirm the execution of, any commodity option transaction on a physical commodity subject to the provisions of subsection (b) of this section if-

(A) the grantor is a person domiciled in the United States who-

(i) is in the business of buying, selling, producing, or otherwise using the underlying commodity;

(ii) at all times has a net worth of at least $\$ 5,000,000$ certified annually by an independent public accountant using generally accepted accounting principles;

(iii) notifies the Commission and every futures commission merchant offering the grantor's option if the grantor knows or has reason to believe that the grantor's net worth has fallen below $\$ 5,000,000$;

(iv) segregates daily, exclusively for the benefit of purchasers, money, exempted securities, ... commercial paper, bankers' acceptances, commercial bills, or unencumbered warehouse receipts, equal to an amount by which the value of each transaction exceeds the amount received by the grantor for such transaction;

(v) provides an identification number for each transaction; and

(vi) provides confirmation of all orders for such transactions executed, includ-

ing the execution price and a transaction identification number ....

Pub. L. No. 95-405, sec. 3(3), \& 4c(d), 92 Stat. 865 (to be codified in 7 U.S.C. \& 6c(d)).

106. Futures Trading Act of 1978, Pub. L. No. 95-405, sec. 3(3), § 4c(c), 92 Stat. 865 (to be codified in 7 U.S.C. \& $6 \mathrm{c}(\mathrm{c}))$.

107. Pub. L. No. $95-405,92$ Stat. 865.

108. As Chairman Bagley has noted, "[i]n determining whether to continue option trading ... the Commission . . . will have to conclude that the option markets are used on more than an occasional basis for other than speculative purposes by producers, processors, merchants or consumers . . . " 1978 House Appropriation Hearings 215 (testimony of William Bagley). See also 43 Fed. Reg. 16,153, 16,155 (1978). This is essentially the same test which the Commission has applied in designating a contract market for a new futures contract. CFTC Public Interest Guideline No. 1, [1975-1977 Transfer Binder] Comm. Fur. L. ReP. (CCH) I 20,041 (1975).

The economic purpose test posed by the Commission for futures and options contracts does not have a specific legislative basis. Rather, the pertinent provisions of the Commodity Exchange Act contain a broader standard, namely, that such trading not be "contrary to the public interest." See CFTC Act of 1974, 7 U.S.C. \& 7(g) (1976); cf. Futures Trading Act of 1978, Pub. L. No. 95405 , sec. 3(3), \& $4 \mathrm{c}(\mathrm{e}), 92$ Stat. 865 (to be codified in 7 U.S.C. $\$ 6 \mathrm{c}(\mathrm{e})$ ) (Congress imposes a public interest test for dealer options).

109. See, e.g., Note, The Role of the Commodity Futures Trading Commission Under the Com. modity Futures Trading Commission Act of 1974, 73 MiCH. L. Rev. 710, 723-25 (1975). 


\section{An Evaluation of Commodity Option Trading}

Although there has been more than a century of discussion and debate, no coherent explanation of the general economic effects of option trading and of the function of options in connection with futures markets has emerged. With the exception of a Department of Agriculture study published in $1934,{ }^{110}$ which made use of very limited data, ${ }^{111}$ there has been no thorough study of the functions and effects of commodity options since privilege trading began in the $1860 \mathrm{~s}^{112}$ However, important theoretical benefits and uses do exist, and the realization of those benefits will justify permanent commodity option trading in a properly regulated forum.

\section{A. The Economic Benefits of Option Trading.}

In attempting to ascertain the benefits of option trading, the analytical focus should center on two principal types of option contracts-exchange-traded options on physical inventories or on futures contracts, and dealer or Mocatta options. ${ }^{113}$

1. Options as a Means of Risk Transfer. Commodity options, like futures contracts, owe their existence to the presence of economic risk. An option, in fact, performs the same function as a futures contract by transferring the risk of an adverse price movement in a particular commodity from one party who wishes to avoid that risk to another party who is more willing or able to assume it. For example, the holder of an unhedged futures position bears a substantial risk that the market price for the underlying commodity will move adversely to his position by the time the delivery month arrives. By granting an option against the futures position, however, that party can pass on to someone else

110. MEHL.

111. Id. 9.

112. This is due in part to the nineteenth century backroom trading that took place at the Chicago Board of Trade. Since all transactions were settled in cash, and no records of the number and size of the trades were maintained by the Exchange, very little empirical data exists for this period. For a brief time after indemnity trading resumed in 1926, however, exchanges of funds were recorded and handled through the Clearing Association of the Chicago Board of Trade. Id. The only volume records that the Department of Agriculture had available in 1934 were maintained by the Bureau of Internal Revenue of the U.S. Treasury Department, which collected a stamp tax on sales of offers (i.e., put options).

113. Dealer/Mocatta options are discussed in the text accompanying notes 58-62 supra.

There also exists a third type of contract-the so-called naked option. See text accompanying notes 43-57 supra. The consensus appears to be that naked options possess no economic utility whatsoever and should not be considered commodity options. See note 56 supra. They will not be considered here for this reason. 
the risk of an adverse price move. ${ }^{114}$ The holder of physical inventory, on the other hand, bears the risk that the market value for his inventory will decline while it is in his possession. In order to pass on this risk, the inventory holder might grant a call option to an interested investor, thus offsetting the price decline by the amount of the premium received. The inventory holder could also purchase a put option which would give him the right to sell his inventory to his option grantor at a favorable price.

The mere function of transferring the risk of changed market values from one person who is illiquid or otherwise unwilling to bear that risk to another who is highly liquid and willing to bear it actually entails a reduction in overall market risk. ${ }^{115}$ This function is, in fact, very similar to that provided by insurance companies for automobile operators or homeowners. For the price of a premium, the insurance policy holder obtains protection against catastrophic loss while the insurance company offsets its potential obligations by the premiums received. ${ }^{116}$ In the commodity markets, the economic benefit of such risk transfers can generally be translated into lower consumer prices for food and other manufactured items. ${ }^{17}$ The importance of this effect of option trading on consumer prices has been strongly emphasized by the President's Council on Wage and Price Stability:

Frequently, those engaged in the production and sale of goods are not best equipped to bear risk. The risk which they do bear is directly translatable into production costs which are passed on to consumers in the prices they pay. The existence of a mechanism, such as the option, for transferring or reducing risk is directly translatable into lower consumer costs. ${ }^{118}$

\section{Increasing the Flow of Funds into the Commodity Indus-} try. Another major advantage of commodity option trading on domestic exchanges is the resulting stimulation of the flow of private investment capital into the commodity markets generally. ${ }^{119}$ In the same way that the securities markets facilitate the flow of capital from those who hold it to those who can put it to the most effective economic use, the public sale of commodity options can attract capital to the com-

114. 1974 House Hearings 197; Baumol 5-9.

115. 1974 House Hearings 197; Baumol 7.

116. 1974 House Hearings 197; see Baumol 8.

117. 1974 House Hearings 199; Baumol 17.

118. Comments of the Council on Wage and Price Stability on Commodity Options Transactions-Proposed Amendment of Interim Regulations 6 (June 6, 1977); accord, 1974 House Hearings 199; Baumol 17.

119. 1974 House Hearings 199; see 1978 House Hearings 116 (letter from Rep. Dan Glickman). 
modity futures markets to assist market participants in their productive activities.

For example, through the use of commodity options a manufacturer can effectively increase the real capital resources under his control. Since a manufacturer can keep a considerable inventory at his command with the relatively small expense involved in purchasing an option, the amount of the manufacturer's own capital tied up in his inventory can be greatly reduced. ${ }^{120}$ The availability of commodity option trading can provide substantial flexibility to a manufacturer or producer by transferring to investors the cost of carrying inventories. Also, instead of holding a simple inventory of raw materials that may be subject to the risk of price volatility, a manufacturer can transform that inventory into a rich variety of investment possibilities, each of which might be attractive to a different group of investors. ${ }^{121}$ By this process, options can provide a flow of funds that will allow producers and manufacturers to function more efficiently.

\section{Limitation of Risk Caused by Price Volatility: Options Versus} Futures. Probably the single greatest advantage of options over futures trading is that the option holder's risk is always limited to the premium paid. An option holder undertakes no obligation to post margins, ${ }^{122}$ whereas the purchaser of a futures contract would be required to post an initial margin deposit and might later be called upon to post substantial "maintenance margins" in the event of adverse price moves. ${ }^{123}$

Although an option holder undertakes no margin responsibilities, he nonetheless obtains an opportunity to observe market price variations for a period of time from a position that is superior to that of the futures contract holder. For example, a period of excessive adverse price movement might force a futures contract holder out of the market if he were unable to post the required maintenance margins. The option holder, on the other hand, can "ride out" such a period of adverse price movement until the expiration date of the contract, at which time the price may have returned to a more favorable level. ${ }^{124}$ Thus, the option holder has an unfettered opportunity to observe periods of high market volatility with no risk of substantial demands on his cash

120. Baumol 17.

121. Id. 18.

122. This is because the option holder has no affirmative responsibility to perform and may abandon the contract without further obligation once his premium has been paid.

123. Note, supra note 44 , at 1425. See note 3 supra.

124. M. POwERS, supra note 13, at 198. See also 1978 House Appropriation Hearings 214 (statement of William Bagley). 
flow. ${ }^{125}$

4. Increased Stability of Futures Prices. A number of experts maintain that option trading has a stabilizing effect on futures prices. ${ }^{126}$ These experts argue that persons holding options for speculative purposes will normally seek to sell when the price of an underlying commodity or futures contract is high and will seek to buy when its price is low. Thus, the speculator is inclined to contribute to the supply of a commodity through his sales when increased demand pushes prices high. This increased supply in turn reduces the upward price push. In the converse situation, a speculator is likely to buy the underlying commodity or futures contract when the price is low, thus adding to the demand and providing an upward impetus for prices. This theoretical assertion has been compared to the experience in the securities markets where the issuance of warrants for convertible bonds (essentially the same as options) has been observed to cause a substantial reduction in price fluctuations for the underlying securities. ${ }^{127}$ In fact, the $1934 \mathrm{De}-$ partment of Agriculture study found that a stabilizing influence seemed to result from privilege trading because speculators tended to trade against price movements, thereby moderating those price movements to a certain extent. ${ }^{128}$ Such a result is indeed beneficial.

In summary, then, options can play an important and beneficial economic role, particularly with respect to limiting risks and stabilizing prices. However, in addition to this economic role, commodity options may be useful aids to trading in the futures market.

125. M. Powers, supra note 13, at 198. See also 1978 House Appropriation Hearings 215 (statement of William Bagley). The risk of an option grantor, on the other hand, is not necessarily so limited. If he is not the owner of physical inventories or the holder of futures contracts sufficient to meet his obligations under the option, the option grantor bears the risk that the price at which he must buy the underlying futures contract or physical inventory to "deliver" under a call option (or the price at which he can dispose of a contract or inventory "put" to him by his optionee) will have moved adversely to the striking price stated in the option. The grantor thus has a risk of exposure to adverse price movements identical to that of the holder of a comparable futures position-except that he has the benefit of an offsetting premium.

There are various ways in which option grantors can protect themselves from otherwise unacceptable risks. As indicated above, the risk is eliminated if the grantor owns a sufficient amount of the underlying commodity or futures contract to meet his obligations under the option. Such a "one for one" matching of inventory and futures with option obligations might, however, prove unduly burdensome to a commercial grantor. Probably the best protection would be provided by a system whereby option grantors were subject to regulation by an exchange and its clearinghouse. This would involve the constant monitoring of market prices to determine which options are "in the money" and the posting of adequate margins to insure the grantors' ability to perform under those options.

126. E.g., Baumol 20; Note, supra note 44, at 1443-44.

127. 1974 House Hearings 200 (statement of Dr. Henry Jarecki).

128. MEHL 70-72; see Note, supra note 109, at 725. 


\section{B. Options as an Aid to Futures Trading.}

Beyond the benefits accruing to the public and to the commodity industry through the use of commodity options, options used in conjunction with futures trading can provide a number of new possibilities for traders. For example, traders often employ options as "stop orders" on futures contracts. ${ }^{129}$ Futures traders frequently attempt to limit their losses by placing a stop order with their brokers instructing them to close out the futures position if the price reaches a certain level. However, this system does not always operate effectively since, in volatile trading, the market price may pass through a stop order price level before the order can be exercised. An option, on the other hand, can give the trader full assurance that he will be able to dispose of his futures position at the chosen price. ${ }^{130}$ Moreover, the option holder can wait out an adverse price move without closing out his futures position. Thus, for the price of a premium, futures traders can obtain precise limitations on their losses-a better result than that presently available through the use of stop orders.

In addition, options can be useful to the holder of a futures position in liquidating that position during a period of rapid price change. Since the futures exchanges impose daily price limits on the extent to which futures prices may rise above or fall below the previous day's settlement figure, ${ }^{131}$ it may not be possible to liquidate a futures position on such a day. However, if the holder has an offsetting option position-which would not be subject to the trading limit-it would be possible to liquidate the option position by placing a market order in the option market to buy or sell the futures contract at the striking price. ${ }^{132}$

Thus, there are apparently a number of ways in which option trading can create economic benefits. However, the Commission has proved unwilling to allow the resumption of option trading solely on the basis of bald assertions of their economic utility. Instead, the Commission has proposed a pilot program that will allow limited option trading for a test period. The data assimilated under this pilot program should enable the Commission to determine whether these theoretical economic benefits materialize in actual trading. This determination, in turn, will seal the fate of option trading in the United States. Due to

129. M. POWERS, supra note 13 , at 199.

130. See id.

131. See, e.g., Chicago Board of Trade, Rules and Regulations, Reg. 1823 (1976).

132. The holder can thus obtain the right to purchase a futures contract at a price that would not have been permitted in that day's futures trading. For a discussion of this point, see 1978 Senate Hearings 153 (statement of Dr. Hendrik Houthakker). 
the gravity of the decision facing the Commission, two questions must be considered: first, is the pilot program structured to generate the empirical data necessary to ascertain the existence of economic benefits arising from option trading and, second, do adequate standards exist to evaluate such data once it has been obtained?

\section{The Proposed Pilot Program}

In addition to the interim or Part $A$ regulations outlined above, ${ }^{133}$ the Commission contemplated a second phase or Part B series of regulations that would provide for a three-year pilot program under which the Commission can gather sufficient empirical evidence to determine whether option trading should be allowed on domestic commodity exchanges and, if so, on what basis. ${ }^{134}$ According to the Commission, only the existence of economic benefits will justify a continuation of this activity. The goal, as the Commission sees it, is to "make a judgment whether or not option trading involving the newly-regulated commodities is contrary to the public interest." 135

The Part B regulations proposed by the Commission would restrict commodity option transactions to those executed on or subject to the rules of a domestic or foreign commodity option exchange, provided that certain additional requirements concerning foreign options are met. ${ }^{136}$ This provision would effectively outlaw the offer and sale of "naked" options and other options not traded on an exchange. ${ }^{137}$ With respect to customer protection, the Part B regulations for the most part carry forward the provisions of the Commission's interim regulations concerning the registration of option firms as FCMs, the segregation of customer funds, the mandatory disclosure of risk to customers and the maintenance of proper books and records. ${ }^{138}$

Basically, the system proposed for regulating domestic option trad-

133. See text accompanying notes $80-82$ supra.

134. 1978 House Appropriation Hearings 491, 631 (Report on the CFTC prepared by the Surveys and Investigations Staff of the House Comm. on Appropriations).

135. 1978 House Appropriation Hearings 462.

136. 42 Fed. Reg. 55,550 (1977) (to be codified in 17 C.F.R. $§ 32.3(a)$ ).

137. However, off-exchange trading of trade options between commercial entities would be permitted under section 32.2(a). See note 96 supra. The proposed regulations have not yet dealt with the issue of dealer options. Nonetheless, in the explanatory text accompanying the proposed regulations, the Commission indicated that it is willing to permit the trading of dealer options if it can be convinced that appropriate safeguards can be provided to account for the absence of a clearing mechanism. 42 Fed. Reg. 55,538, 55,540 (1977). Since the Commission has subsequently adopted a specific exemption for dealer options under its June 1, 1978 ban, 43 Fed. Reg. 23,704 (1978) (to be codified in 17 C.F.R. \$ 32.12), it appears likely that dealer options will be included in the pilot program.

138. 42 Fed. Reg. 55,553 (1977) (to be codified in 17 C.F.R. $\S 32.6(d)$, (e) and (f)). 
ing parallels that which applies to trading in futures contracts. The Commission would regulate the exchanges by designating them as "domestic commodity option exchanges" and would have the authority to review and approve the rules, by-laws and resolutions of each exchange. ${ }^{139}$ Most of the mechanical details of trading option contracts, such as the margin requirements, clearing procedures and the delivery process, would be left up to the exchanges themselves. ${ }^{140}$ Finally, the Commission proposes to limit the speculative leverage of option traders to some extent by prohibiting the margining of option premiums. ${ }^{141}$

Within the framework of its Part B regulations, the Commission has indicated its intent to license each exchange to trade options for no more than one commodity, and to issue no more than one license to trade options for each commodity. A further limitation will likely be that an exchange will be eligible for designation for a particular option only if it is also designated as a contract market for the underlying futures contract. ${ }^{142}$

The original version of the Part B regulations, published on April 5,1977 , would have limited option trading on domestic exchanges to call options. In response to strong comments from the industry that there may well be more economic justification for put rather than call option trading on certain commodities, this provision has been broadened to allow both put and call options under the pilot program. ${ }^{143}$ However, the Commission has stated that it does not intend at the outset to license the same exchange for trading in both put and call options on the same commodity. ${ }^{144}$

One of the major shortcomings of the pilot program is the narrow limits that it will place on option activity. While limiting each exchange to a single option contract and not allowing an exchange to offer both puts and calls on a commodity may be desirable in terms of

139. 42 Fed. Reg. $55,544,55,553,55,555$ (1977) (to be codified in 17 C.F.R. $\S \S 32.6(a)$ and 32.13).

140. 42 Fed. Reg. 55,542 (1977). The proposed regulations would, however, impose certain specific requirements on the manner in which options could be traded. For example, the exchanges would be required to make available for dissemination by FCMs to their option customers a standardized disclosure statement and to give notice to an option grantor upon exercise of each option on a futures contract. Certain delivery requirements would also be imposed with respect to options on physical commodities.

141. See CFTC Staff Memorandum, Margining of Option Premiums (Feb. 10, 1978); 42 Fed. Reg. 55,551 (1977) (to be codified in 17 C.F.R. § 32.5(a)(1)(ii)).

142. See CFTC Staff Memorandum, Issues Raised by Part B of the Commodity Option Regulations 2-3 (Jan. 18, 1978). See also 1978 House Appropriation Hearings 215 (testimony of William Bagley).

143. 42 Fed. Reg. 55,538-39 (1977).

144. Id. 55,539 . 
the Commission's workload, those restrictions may seriously impair the program's effectiveness as a means of developing valid data about the economic utility of options and the impact of options on futures trading. The Senate Agriculture Committee, in fact, has objected to these limitations:

The committee is concerned with the Commission's announced plans for a "pilot program" of exchange trading of commodity options in which a limited number of commodities would be traded on a limited number of exchanges. History indicates that pilot projects of the kind envisioned by the Commission may become permanent regardless of the results of the study. (It may also be questioned whether exchange traded commodity options can be successfully evaluated in such a limited program.) ${ }^{145}$

The Commission's own Advisory Committee on the Definition and Regulation of Market Instruments has taken the position that the marketplace should be allowed the benefits of unrestricted option trading unless it can be demonstrated that a particular form of option trading is contrary to the public interest. ${ }^{146}$ Inasmuch as the Commission has made no determination that options on a particular commodity are inherently dangerous and there is no reason to suspect that protection cannot be provided to customers of exchange-traded options, the Advisory Committee clearly feels that the domestic option program should not be unduly restricted. ${ }^{147}$

Since the purpose of the pilot program is to test the utility and effect of option trading, it seems counterproductive to impose restrictions that threaten the program's usefulness for that purpose. The best arbiter of the types and number of options to be traded is the marketplace itself, and the Commission should allow the market to play its natural role in the test program. ${ }^{148}$

145. S. REP. No. 850, 95th Cong., 2d Sess. 24 (1978).

146. Specifically, the Committee noted:

The Advisory Committee does not believe that any particular form of option trading should be prohibited, absent a finding that such transactions (A) are illegal or inherently fraudulent or manipulative, or (B) are contrary to the public interest in that they have a material adverse economic effect on futures markets or otherwise, or (C) do not provide three of the basic consumer protections afforded to users of contracts markets [i.e., segregation of customer funds, a mechanism guaranteeing performance of the option, and adequate supervision of trading practices].

ADVISORY COMMITTEE REPORT 16.

147. Id. 15-16.

148. There are certain valid limitations to consider. For example, because of the problems inherent in "delivering" futures positions that are traded on an exchange different from the exchange trading the option contract, options should be restricted to the exchanges trading the underlying futures contract. Likewise, a proliferation of a given option contract on many different exchanges might cause problems in liquidity. Cf. CBOE Says Options Shouldn't Be Traded On Any More Markets, Wall St. J., Sept. 28, 1978, at 32, col. 2 (referring to proliferation problems in stock options). However, the nature of the options themselves, the commodities on which options 
The pilot program has other shortcomings. In order to support a continuation of commodity option trading after the three-year test period, the Commission has stated that it must assure itself that commodity options in general, and specific options in particular, meet three requirements: first, they must serve an economic purpose; second, they must be offered and sold consistent with adequate protection of option customers; and, third, they must not have a material adverse effect on domestic futures or cash markets. ${ }^{149}$ Thus far, the Commission has done little more than to state these three criteria. It has not undertaken to define specifically what is meant by each test and has developed no standards for measuring success or failure. ${ }^{150}$ While it is unreasonable to expect the Commission to detail in advance the economic purposes that option trading should serve or the specific "danger zone" with respect to adverse impact on customers or the futures markets themselves, clarification is nonetheless essential. For example, there is a great range of opinion concerning what constitutes economic purpose. Some commentators, including the Advisory Committee on Market Instruments, argue that any form of economic activity should be permitted unless the public interest is so adversely affected that it should be prohibited. ${ }^{151}$ On the other hand, the Commission apparently takes the view that only substantial commercial-as opposed to speculative-participation in option activity will show economic purpose. ${ }^{152}$ The Commission must first define economic purpose if the pilot program is to accumulate the information necessary to determine whether such a purpose exists.

\section{A. The Economic Purpose Test.}

In order to determine whether domestic option trading serves an economic purpose, it will be necessary to develop a framework for generating the requisite empirical information. As indicated above, numerous economic uses or benefits that may result from the trading of commodity options on domestic exchanges have been identified. ${ }^{153} \mathrm{Al}-$ though they cover a broad range, these economic justifications can reasonably be placed in certain categories: first, economic benefits to the

\footnotetext{
are traded, whether there are puts and calls or both, and the rules relating to trading and margin requirements should be left to the exchanges.

149. 1978 House Appropriation Hearings 462.

150. See text accompanying notes 209-18 infra.

151. ADVISORY COMMITTEE REPORT 15.

152. In fact, the Commission recently stated before the House Appropriations Committee that foreign and dealer options have been sold almost exclusively as speculative instruments and that they therefore do not serve any useful economic purpose. 1978 House Appropriation Hearings 462.

153. See text accompanying notes $110-32$ supra.
} 
parties engaged in option trading, ${ }^{154}$ second, facilitation of the price discovery and price protection functions of the futures markets, ${ }^{155}$ and, finally, economic benefits to society as a whole. ${ }^{156}$ At this point, however, the Commission does not appear to recognize all of these levels of economic use or benefit as factors for determining the success of its pilot program. Rather, the Commission appears more concerned about the identity of the purchaser of commodity options and his reasons for purchasing. In the preamble to the Part $B$ regulations published on October 17, 1977 the Commission stated:

One of the purposes of the pilot program is to determine whether option contracts traded on licened [sic] domestic commodity option exchanges will be used by producers, processors, merchants, or consumers engaged in handling or utilizing the commodity (including the products, by-products or source commodity thereof) underlying the contract. ${ }^{157}$

The Commission has further stated that in order to justify a continuation of option trading it must "conclude that the option markets are used on more than an occasional basis for other than speculative purposes . . ." by such parties. ${ }^{158}$

However, trying to determine that hedging by a commercial user, for example, is a valid economic purpose and that "speculation" by a private investor is not may prove to be a hindrance to the smooth and efficient functioning of the option markets rather than sound regulation. In the view of one of the principal theoreticians of the modern American commodity futures markets, it is impossible to draw a valid distinction between pure speculation and the supposedly more valid economic function of hedging. ${ }^{159}$ Thomas A. Hieronymus argues that

154. Both the hedging possibilities for commercial users and the investment possibilities for speculators would be encompassed by this category.

155. Increased market liquidity and the narrowing of price differentials fall into this category.

156. The reduction of prices for food and other consumer goods would be included here.

157. 42 Fed. Reg. 55,539 (1977).

158. 1978 House Appropriation Hearings 215 (testimony of William Bagley). The historical bias against speculation thus appears to be the basis for the Commission's standard of economic purpose. The accuracy of this assertion becomes all too clear upon perusal of the "Resolution declaring dangerous tendency of dealings in commodity futures," 7 U.S.C. $\$ 5$ (1976), which was first included in the Grain Futures Act of 1922 and still exists with no appreciable alteration under the CFTC Act of 1974. The resolution states:

[T]he transactions and prices of commodity on such boards of trade are susceptible to speculation, manipulation, and control, and sudden or unreasonable fluctuations in the prices thereof frequently occur as a result of such speculation, manipulation, or control, which are detrimental to the producer or the consumer and the persons handling commodity and products and byproducts thereof in interstate commerce, and such fluctuations in prices are an obstruction to and a burden upon interstate commerce in commodity and the products and byproducts thereof and render regulation imperative for the protection of such commerce and the national public interest therein.

159. See generally T. Hieronymus, Economics of Futures Trading chs. 6, 7, and 9 (1971). 
all trading is really speculation and that it is all necessary to the functioning of the futures markets. ${ }^{160}$ According to Hieronymus, "hedging" is speculation in the relationship between cash and futures prices, while "speculation" is speculation in price level changes in the futures market. ${ }^{161}$

Another commentator has pointed out that, even aside from the theoretical difficulties, the speculator/hedger distinction may be unwarranted from a regulatory standpoint. In testimony before the House Committee on Agriculture in 1974, the then Iowa Superintendent of Securities pointed out:

The classic assumption that hedging was totally virtuous-and speculation but a necessary evil-may have hidden from notice and attention the rankest sort of speculation, with possible attendant price distortion, possibly engaged in by the large-scale hedgers, among whom large grain companies are numbered. In a word, if any single set of interests are in a possible position to manipulate a commodities market, that set of interests is more likely to have been self-classified as 'hedging'-and accepted by existing regulation as occupying that role. ${ }^{162}$

This commentator went on to advocate a shift in the focus of commodity regulation toward the encouragement and protection of the speculator. $^{163}$

Finally, it might even be possible to turn the Hieronymus theory on its head and state that all speculation is in fact "hedging" or risk avoidance. Given that the concern over inflation has continued and intensified during the 1970s and that other forms of investment such as securities have proven less attractive as a means of protecting the value of an investor's assets, it may be accurate to state that most private

160. Id.

161. As Hieronymus puts it:

It is sometimes said that hedging is the opposite of speculation. This is not so. They are different kinds of the same thing. The thing that is usually identified as speculation - that is, long or short positions in futures contracts [without an off-setting possession of the physical commodity]-is speculation in changes in price level. The thing that we identify as hedging - that is, long cash [i.e., possession of the physical commodity] and short futures or vice versa - is speculation in price relationships. We may be able to make this difference clearer by considering the case of a farmer with a bin full of wheat. $\mathrm{He}$ is long cash wheat. He is speculating in the level of wheat prices and in the relationship of the price of his specific lot of wheat to the general level of wheat prices. If he hedges, he ceases to speculate in the level of wheat prices while continuing to speculate in the relationship of his wheat to the general level. Thus, hedging and speculation are not opposite; in fact they are conceptually similar. They are just different kinds of speculation.

Id. 151.

162. 1974 House Hearings 183 (statement of Glenn Willett Clark). See also Note, Abuses In the Commodity Markets: The Need For Change In The Regulatory Structure, 63 GEO. L.J. 751, 758 (1975).

163. 1974 House Hearings 183 (statement of Glenn Willett Clark). 
investors have been attracted to commodity options during this period as a means of hedging. ${ }^{164}$

Certainly, there are uses of options other than commercial hedging that produce an economic benefit. It is hard to understand how reduced consumer prices or a lessening of price volatility in the futures markets could not be considered an "economic purpose." The basic question to be answered in formulating proper standards is at what level do we ask the question? Deciding whether economic purpose exists presumably can involve an examination of three distinct levels of economic effect: on the individual traders themselves, on the cash commodity and futures markets, and on the American economy as a whole. Very likely, the nature and degree of benefits will be different at each level. In any case, the Commission's concept of economic purpose is too narrowly focused on the purposes for which the parties involved may enter into an option transaction.

Another difficulty that may arise from the Commission's emphasis on the identity of the trader and his purposes for trading is a definitional one. Apart from the theoretical problems in differentiating between hedging and speculation noted above, the attempt to distinguish between commercial and speculative trading may lead the Commission into a definitional trap similar to the one that plagued the Illinois legislature, the courts and Congress throughout the latter nineteenth century-the Commission will be unable to define the evil to be prevented and its efforts to regulate will therefore be ineffective. ${ }^{165}$ Just as the

164. Economist Hendrik Houthakker of Harvard University supports this view. See 1978 Senate Hearings 155 (statement of Dr. Hendrik Houthakker).

165. Professor Houthakker has expressed the view that if the Commission's present standards had been applied in the nineteenth century, there would never have been futures contracts in the first place. Id. 152. The Illinois Act of 1874 banning commodity privilege trading, ILL. REv. STAT. ch. 38, \& 130 (1874), proved difficult to enforce because of the conceptual affinity between legitimate futures trading and prohibited privilege trading. The test used by the courts to distinguish the two was whether the parties intended delivery under their contracts. See J.B. Lyon \& Co. v. Culbertson, Blair \& Co., 83 Ill. 33 (1876). Unfortunately, it was already common practice to enter into futures contracts that would be closed out by settlement or offset rather than by delivery. Even though most of the contracts executed by exchange members involved no actual delivery of the grain, $i d$., the Illinois court uniformly insisted that delivery was required before a contract could be enforced, $i d$. at 44 . The court did manage to expand the definition of "delivery" in an attempt to legitimize the normal and harmless futures trading that occurred on the grain exchanges. However, more than anything, the cases produced a great amount of uncertainty as to what types of contracts were acceptable. Compare Clarke v. Foss, 5 F. Cas. 955,960 (W.D. Wis. 1878) (No. 2,852) with Cothran v. Ellis, 125 Ill. 496, 501 (1888) and Webster v. Sturges, 7 Ill. App. 560,564 (1880).

The difficulty faced by the Illinois courts during this period was that they were unable to discover an adequate definition of the evil to be prevented so that it could be distinguished from legitimate economic activity. There was a strong sense that trading in price differences, where no transfer of property was ever contemplated, should be prohibited. On the other hand, futures 
Illinois legislature and Congress were unable to distinguish between legitimate trading based upon price differences and "gambling," so the Commission will find it impossible to define which forms of speculation are harmful and which are not. For example, assuming the Commission determines that not all speculation is bad and therefore is to be eradicated, how will it decide what types of activity to restrict or prevent? Are certain option transactions to be prohibited because the parties enter into them only because of their respective guesses at future price movements? Or is the so-called speculative activity in options to be cut off when it reaches a certain percentage of market transactions? And what would be an appropriate percentage at which to curtail such activity? Clearly, the Commission needs to develop a standard that does not focus upon the motivation of the players.

\section{B. Customer Protection.}

The second major requirement that the Commission has established under the Part B pilot program is that the system must provide adequate protection to the investing public. The criticism generated by the Commission's failure to protect the public from firms such as Lloyd Carr ${ }^{166}$ guarantees that the Commission will be most insistent about this requirement and will conduct an intensive scrutiny of any customer complaints that may arise under the pilot program.

At this stage in its development, the Commission probably knows more about protecting customers from fraud and sharp practices than it does about any other aspect of option regulation. However, the Commission's experience up to this point has been primarily with foreign or London options. Because domestic options and dealer options present substantial new complexities and concerns, a proper analysis of the proposed regulatory system should include a review of each option type in turn.

1. Domestic Options. The introduction of commodity option trading on the domestic exchanges will bring with it certain basic protections that will avoid many of the problems that have accompanied off-exchange trading in the past. Exchange-traded options will involve the competitive bidding of premiums at public outcry. This should

trading on the Board of Trade was recognized to have great economic utility even though it often involved settlement based on price differences. See Porter v. Viets, 19 F. Cas. 1077 (C.C.N.D. Ill. 1857) (No. 11,291). The gradual development of a test based upon the parties' "intent" to deliver was the best the courts could do to resolve the dilemma.

166. See note 85 and text accompanying notes $84-90$ supra. 
produce generally lower investment costs to option customers. ${ }^{167} \mathrm{But}$ perhaps most importantly, the domestic exchanges will provide clearinghouse protection for each option contract. ${ }^{168}$ Presumably, this clearing function will operate in virtually the same manner as that currently provided for futures contracts. The two parties to an option trade would each submit a confirmation to the clearinghouse; the confirmation would be matched in terms of the basic contract terms-including the premium, striking price and option term-and all matched trades would then be posted to the accounts of the clearing members through which the trades were submitted. The clearinghouse, at this point, would become a guarantor to the option purchaser's clearing member, insuring performance under the option contract. ${ }^{169}$

The clearinghouse guaranty should constitute the most important protection to domestic option customers. Because of this undertaking, a customer would know that, although he may still bear the risk of default or bankruptcy by his futures commission merchant, ${ }^{170}$ he would be relieved of the risk of default or bankruptcy by the option grantor. The guaranty obligation issued by a clearinghouse would, of course, necessitate certain procedures designed to protect the clearinghouse from defaults by option grantors. While specific requirements for option transactions are only now being formulated by the domestic exchanges, certain basic elements should be involved.

The first necessary ingredient will be the posting of adequate mar-

167. 1978 House Appropriation Hearings 462. Even though London option premiums, except on the London Metals Exchange, are determined at auction, there has been no competitive bidding among the United States firms offering these options to the American investor. London premium information has not been easily available to the investor, which has often meant that the actual "premiums" or commissions charged have been greatly inflated. The fact that bidding will occur on the United States exchanges and that premium information will be widely published should enable the investor to determine whether he is getting the best price available.

168. Id.

169. The clearinghouse function should operate in the same way it does presently for futures trades, except that the guaranty will be given in only one direction because of the unilateral nature of an option contract. The clearinghouse will guarantee the grantor's performance to each option purchaser.

170. While the option remains open and unexercised, the clearinghouse will most likely hold an original margin deposit only from the grantor (since he is the only trading party with a market risk at this point). The clearinghouse will then mark the position to market each day by comparing the striking price of the option to that day's settlement price for the related futures contract. Once the option is exercised, however, the clearinghouse will convert the unilateral option position to a bilateral futures position in which margin deposits will be required of both buyer and seller. These deposits will thereafter be marked to market the same as all other futures positions. For a description of the mechanics of such a clearing system, see Highlights of Clearing System for Commodity Options, Staff Document on file with the Board of Trade Clearing Corp., Chicago, Ill. As to the treatment of customer claims in the event of a commodity broker's bankruptcy, see the special provisions contained in the new Title 11 of the U.S. Code, Act of Nov. 6, 1978, Pub. L. No. 95-598, §§ 761-766, 95 Stat. 2611-21. 
gins by option grantors to cover the potential risk of default. Presumably, such margins would be determined on the basis of the expected volatility in the price of the underlying futures contract or physical commodity, in a manner similar to the calculation of margins on futures positions. ${ }^{171}$ The clearinghouse would then wish to make daily adjustments in the required deposits (generally called "marking to market") to account for any increased risk to the grantor resulting from price movements in the underlying futures contract. This marking to market would involve a daily comparison of the option striking price with the daily closing or settlement price for the underlying futures contract, and a corresponding call for additional deposits would be issued when necessary to cover the difference.

The difficulty would arise when a grantor was unable or unwilling to meet a demand for additional deposits. In such a case, the clearinghouse would have several options. It could take over the existing deposit and at the same time obtain a futures contract for its own account to protect against further price exposure. Under its guaranty, the clearinghouse presumably would be obligated to make good the difference between the price of the futures contract purchased and the amount of the grantor's deposit. This procedure would have the advantage of providing substantial protection against the option guaranty, but it would have the disadvantage of exposing the clearinghouse to losses under the futures contract that may exceed the amount of the grantor's deposit. Another possible solution might be for the clearinghouse to transfer the option account to another clearing member who is willing to accept it. If this could be accomplished, it would have the effect of bringing the account "current" and allowing the normal margining process to continue.

Another means by which an exchange or its clearinghouse might provide protection against grantor defaults would be to require that each option contract be backed to some degree by ownership of the underlying physical commodity or the requisite futures contract. While it might be possible to require that options be backed $100 \%$ by the underlying commodity or futures contract, this would require much greater coverage than necessary to meet the actual market risk of the grantor under each option. Rather, it should be possible to develop a set of rules that would take into account any offsetting positions a grantor might hold in the underlying commodity or futures contract and to make an appropriate adjustment in the margin requirements for that

171. In the case of the ICCH in London, the deposit required of the grantor of an option is, in fact, the same as that required for the underlying futures contracts. ICCH, Clearing for Commodity Options 7 (1978). 
grantor. ${ }^{172}$

2. Foreign Options. A more serious challenge to CFTC protection of option customers exists with respect to foreign options. There is a great deal of variation in the practices and procedures of the different London exchanges with regard to clearing trades, segregating customer funds and requiring deposits and margins from option grantors. ${ }^{173}$ The Commission first indicated that it would require the foreign exchanges to apply for approval of their contracts and procedures to insure adequate and uniform protection of American option customers. ${ }^{174} \mathrm{How}-$ ever, because of the strenuous opposition of London exchanges to the assertion of extraterritorial jurisdiction, the Commission has revised its proposal to impose requirements instead on the FCMs marketing foreign options in this country. With respect to options traded on the London exchanges whose transactions are cleared by the $\mathrm{ICCH}$, the proposed regulations would require that the FCM be a clearing member of the ICCH. ${ }^{175}$ As to options traded on the London Metal Exchange (LME), the Commission would require that the FCM obtain a standardized option contract between the customer and a ring-dealing member of the exchange, obligating that member to guarantee performance of all option obligations directly to that customer. ${ }^{176}$

The reason for the Commission's concern over foreign options is obvious. In the past, the problem with such options has not necessarily been with the London exchanges or their members, or with the adequacy of the safeguards provided by those exchanges. ${ }^{177}$ Rather, the problem has been that the segregated premiums, margin deposits and/or clearinghouse guaranties have not been available to satisfy the claims of aggrieved customers in this country. Most, if not all, of the American customers' accounts have been carried on an omnibus basis with the London exchange members, and these customers have been unable to trace their accounts in the event of insolvency of their FCMs. ${ }^{178}$

172. The treatment of cross-trades by the $\mathrm{ICCH}$ might serve as a useful example of this treatment. If a member has opposite option positions posted to its account, the clearinghouse recognizes an offset with respect to the deposit requirements. This corresponds to the so-called "netmargin" system currently used by a number of United States exchanges.

173. See note 35 supra.

174. 42 Fed. Reg. 55,540 (1977).

175. Id. 55,544 (to be codified in 17 C.F.R. $\$ 32.7(\mathrm{a})$ ).

176. 42 Fed. Reg. 55,554 (1977) (to be codified in 17 C.F.R. $\$ 32.7(b)$ ).

177. 42 Fed. Reg. 55,541 (1977).

178. Id. 55,546. An "omnibus account" is one that is carried by an exchange clearing member in the name of a nonclearing member FCM for which the principal owner or owners of the accounts are not disclosed to the clearing member. 
To deal with this problem, the Commission has taken two steps. First, it requires direct privity of contract between the American customer and the firm for whose benefit the clearinghouse guaranties or margin deposits exist. Second, it requires that foreign option customer funds be segregated from all other funds. Moreover, the segregated funds may not be used to offset the claims of a foreign exchange or its clearinghouse against the FCM, that is, they may not be counted as a margin deposit. ${ }^{179}$ These measures should greatly improve the degree of protection afforded to American purchasers of London options. The requirement of ICCH membership probably will reduce greatly the participation of thinly capitalized, disreputable firms in the option business. In addition to examining the financial stability of applicants for membership, the ICCH has indicated that it will take into account the membership of an FCM in a London Terminal Market Association or a clearing membership on a major American exchange. ${ }^{180}$ This indicates an inclination on the part of the ICCH to admit only American firms that have an established reputation and considerable financial substance.

Options issued on the LME present more uncertainty with respect to the stability of the FCMs offering them. While it is likely that the ring-dealing members will exercise some discretion in choosing the American firms with which they will deal, they will have far less concern over the financial substance of those FCMs than does the ICCH, which must rely directly on the American firms to meet their deposit and guaranty obligations to the clearinghouse. Also, the ring-dealing members will not be particularly concerned with the sales practices of the FCMs, since they will have no liability to American customers except for default under the option contracts themselves. The result may be that small, undercapitalized and not necessarily reputable FCMs will enter the foreign metal options market and will present regulatory difficulties for the Commission.

The only reliable solution to this regulatory problem is to require that LME options be cleared by an approved clearing mechanism. During the course of the congressional oversight hearings, a representative of the commodity option industry recommended that a United States clearinghouse be established to provide protection to American customers purchasing foreign options. The suggestion was that such a

179. Id. 55,558 (to be codified in 17 C.F.R. $\$ 32.16(\mathrm{~b})$ ). This provision may be modified somewhat in view of the provisions of the 1978 Act which would give the Commission discretion to allow commingling of various types of customer funds.

180. See comments concerning the proposed further amendment of Interim Regulations on Commodity Options Transactions filed with the CFTC on behalf of the London Commodity Exchange Company, Ltd. and the International Commodities Clearing House, Ltd. 12 (Dec. 2, 1977). 
clearinghouse could become an associate member of the ICCH and yet be subject to full CFTC jurisdiction. ${ }^{181}$

While an American clearinghouse might work for ICCH-guaranteed options, it would probably fail for LME options. The reason is that the ring-dealing members of the LME are not presently required to post margin deposits on options they issue. Since most of the expected volume in LME contracts would be call options purchased by United States investors, there would very likely be no grantor willing to put up margin funds with such a clearinghouse. Without those deposits, a clearinghouse could not function, and unless a clearing mechanism or its equivalent can be devised, such LME options might present insoluble problems of consumer protection. In short, they should be banned.

3. Dealer Options. The possibility of dealer option trading under the proposed pilot program presents a different set of concerns with regard to customer protection. In fact, the Commission originally proposed to ban all off-exchange trading, including dealer options, on the theory that no clearing mechanism or its equivalent is available and that supervision of trading practices would be difficult. ${ }^{182}$

However, a suitable protection equivalent to that provided by a clearing mechanism can be provided. Mocatta Metals Corp., for example, has outlined for the Commission its own procedures and policies, which are designed to insure performance of its option obligations. As a clearing equivalent, Mocatta matches buyer and seller by issuing a number designation for each option and provides for registration in the ultimate purchaser's name, if requested. ${ }^{183}$ It then segregates premiums, and deposits in a separate account the daily marked-to-market profit on all "in the money" options outstanding. ${ }^{184}$ Mocatta guarantees performance under each option granted, thus exposing its substantial net worth to customer claims for default. ${ }^{185}$

While the program outlined by Mocatta appears adequate to provide a substitute for clearinghouse protection, it is not clear whether the

181. 1978 House Hearings 428 (statement of Leonard Goldstein).

182. 42 Fed. Reg. 55,539-40 (1977).

183. See Comments Regarding Proposed Commodity Option Regulations Submitted to the CFTC by Mocatta Metals Corp. 7-8 (Dec. 1977); Petition for Interim Rulemaking Before the Commodity Futures Trading Commission, filed by Mocatta Metals Corp. and Metals Quality Corp. (May 11, 1978), 43 Fed. Reg. 21,002, 21,023-25 (1978).

184. Comments, supra note 183 , at 8 .

185. Id. 9. Basically the same customer protection measures are followed by Dowdex Corp., the other principal commodity option dealer currently operating in the United States. See Petition for General Exemption from the Provisions of Regulation Section 32.11 of the Commission's Regulations, filed for Dowdex Corp. with CFTC (April 24, 1978). 
Commission, as a matter of regulatory policy, should leave the details of a performance guaranty system up to the party whose performance is to be guaranteed. The Commission has taken the first step toward developing a standard set of requirements for dealer option grantors by setting out specific requirements in its temporary dealer option exemption for segregation of premiums, marking-to-market and minimum net worth for a grantor. ${ }^{186}$ This approach has the advantage of establishing uniform requirements that apply to any firm that may engage in granting dealer options.

However, such a system lacks the element that has made the clearing system so effective for the futures markets: objectivity in determining and applying performance guaranty standards. Because of the inherent conflict of interest that is present in a "clearing" system administered by the option grantor, the functions of holding segregated funds, marking-to-market and making demand for the posting of daily option profits are better placed in an independent clearinghouse. ${ }^{187}$

Establishing such a clearing system for dealer option transactions presents obvious problems. It flies in the face of tradition, since metals dealers, who have been the most active grantors of dealer options, have not historically been required to clear option trades. ${ }^{188}$ Such a requirement has not existed previously because trading in commodities often begins in a dealer market before there is sufficient demand to justify exchange trading. ${ }^{189}$ This means that there is too little volume to warrant a standardization of contracts, an inspection and grading system for the underlying commodities, and a fixed delivery system. Certain problems such as the availability of inspection and grading facilities and the proximity to cash markets to facilitate delivery would require solutions before implementing such a system.

The benefits of a clearing system possibly can be approximated if grantor procedures are closely monitored by the CFTC. One approach is to impose a high net worth requirement on dealer option grantors as a substitute for the guaranty fund held by a clearinghouse. ${ }^{190}$ This sys-

186. 43 Fed. Reg. 23,707-08 (1978) (to be codified in 17 C.F.R. $\$ 32.12$ ).

187. From a regulatory standpoint, the objectivity achieved by having an independent clearinghouse is important. It assures that the group of people making determinations about the amount of deposits necessary to insure performance are not subject to the conflicting desire to minimize the demands on their own cash flow and to maximize their profits. This need for objectivity, in fact, was the basis for the decision by the Secretary of Agriculture in 1925 to insist that the Chicago Board of Trade establish a wholly separate and independent clearinghouse. See Chicago Tribune, July 8,1925 , at 15 , col. 1 .

188. See note 35 supra (London Metals Exchange).

189. Oral testimony of Dr. Hendrik Houthakker before the Commission on May 26, 1977; Comments, supra note 183, at 6.

190. See 43 Fed. Reg. 23,704-06 (1978). 
tem has a certain appeal since default under an option contract would expose the grantor's entire net worth to damage claims, but such a system also has a number of drawbacks. First, in a clearing system, contract guaranties are backed by the clearinghouse guaranty fund which is held in the highly liquid forms of cash, government obligations and negotiable securities. The net worth of a grantor, on the other hand, might exist in the forms of buildings, computer equipment, futures and option positions, and other less liquid assets. Second, a clearing system spreads the risk of default or insolvency among its clearing members since the funds on deposit by each stand good for the others' contracts. ${ }^{191}$ A dealer option grantor who defaults or goes bankrupt might leave nothing behind to back up its guaranties beyond the customers' own funds held in segregation.

Another major shortcoming of the grantor net worth approach is that a fixed requirement cannot take into account the constantly changing volume of outstanding option obligations. If the net worth of a dealer is viewed as a substitute for a clearinghouse guaranty fund, it must somehow relate to the magnitude of the dealer's outstanding obligations. ${ }^{192}$ As suggested by the Advisory Committee on Market Instruments, a minimum net worth requirement should be set that would be increased as open option positions created by the grantor increase. ${ }^{193}$ It may very well be that the volume of dealer option trading will diminish after the pilot program is adopted. Presumably, the competition, greater financial safeguards and reduced transaction costs provided for exchange-traded options will make them more attractive to the general public. However, to the extent that dealer options become widely sold to the general public, the Commission should examine closely the possibility of requiring a sounder and more objective system for guaranteeing dealer option transactions.

Finally, it may be difficult to control the manner in which dealer options are sold to the public. Whereas an exchange has a considerable degree of authority to observe and regulate the conduct of its members, a dealer option grantor does not have such control over the FCMs mar-

191. Some clearinghouses, like the Board of Trade Clearing Corporation, are separate stock companies in which clearing members are required to purchase a number of shares commensurate with the volume of their trading activity. Since the clearinghouse guarantees all trades, both to the buyer and to the seller (or, more precisely, to the buyer's clearing member and to the seller's clearing member), this paid-in capital stands as the financial backup for all trades cleared. The margin account of a clearing member, on the other hand, is separate from the clearing corporation's capital account, and it stands as a security deposit for the trades cleared through that clearing member. See discussion of clearing procedures in T. HiERONymus, supra note 159, at 40-43.

192. With clearinghouse stock, for example, the amount required to be paid in by each clearing member is a function of the volume of trading done by that member. See note 191 supra.

193. AdVisory CoMmitee RePORT 46. 
keting its options. The more substantial dealer option firms have had some success in developing customer protection programs with which their FCMs have agreed to comply. ${ }^{194}$ However, since these dealers lack the manpower and enforcement capability of the exchanges and the investigative powers of the CFTC, it is clearly more difficult for them to police the selling of their options. While the Commission presumably will require that any FCMs selling dealer options to the public must meet the minimum capital requirements and the consumer protection rules applicable to FCMs generally, ${ }^{195}$ the policing of FCMs selling dealer options will undoubtedly add to the Commission's regulatory burdens.

One solution would be to require that any FCM offering and selling dealer options to the public must be a member of one of the futures or option exchanges. This would ensure that the firms dealing with the public would be subject to the continuous auditing and surveillance procedures of an exchange that would provide a better system of monitoring than the Commission is presently able to provide. Because of its possible anticompetitive aspects, such a requirement would have to be evaluated carefully by the Commission. However, in view of the major difficulties the Commission has experienced in protecting the public in off-exchange option transactions, such a requirement would seem justified. ${ }^{196}$

The climate for commodity option trading should be substantially improved under the pilot program. Exchange supervision of trading and clearinghouse guaranties for exchange-traded options will lend to options the same types of financial protections that have guarded the

194. See, e.g., Comments, supra note 183 , at 11.

195. Under the revised minimum financial requirements published on September 8, 1978, all FCMs offering to sell options are required to maintain a minimum "adjusted net capital" of $\$ 50,000$ if they are members of an exchange or $\$ 100,000$ if they are nonmembers. This financial "cushion" will provide an element of protection to customers over and above the financial protection provided by the segregation of customer funds under section 32.16 of the Part B regulations and, in the case of domestic options, by the clearinghouse guaranty. Such new minimum financial requirements should provide substantially more protection to option customers than has existed under the interim regulations. See 43 Fed. Reg. 39,956-82 (1978) (to be codified in 17 C.F.R. $\S$ 1.17).

196. Under 7 U.S.C. $\S 19$ (1976), the Commission is required to "endeavor to take the least anticompetitive means of achieving the objectives of [the Commodity Exchange Act] . . . "Id. However, the Commission has interpreted this as a requirement merely to give consideration to the antitrust implications of its actions and not as a limitation on its authority to regulate. In implementing this interpretation, the Commission has imposed a higher minimum financial requirement on FCMs that are not exchange members, 43 Fed. Reg. 39,972 (1978) (to be codified in 17 C.F.R. $\S 1.17(a)(1)$ ), and has provided a dealer option exemption even though it had determined that only a single grantor could meet its requirements. 43 Fed. Reg. 23,706 (1978). 
futures markets for many decades. The implementation of independent clearing procedures for foreign or dealer options should also provide safer investments for the public. The competitive bidding of exchange option premiums, the rapid dissemination of premium information on all options and mandatory disclosures should virtually eliminate the abuses that have characterized off-exchange option trading. Despite the magnitude of past difficulties in providing customer protection, the Commission should be able to structure its program to avoid most of the problems with which it has been plagued in the past.

\section{Effect of Option Trading on the Underlying Futures Markets.}

Probably the least predictable result of domestic option trading is the effect it will have on activity in the underlying futures contracts. Since so little empirical evidence is available, it is virtually impossible to anticipate all of the types of problems that may result.

The volume of option trading as compared to that in the underlying futures is a matter that can only be learned from experience. In the 1934 study, the Department of Agriculture estimated that privilege trading on the Chicago Board of Trade was equivalent to about fifteen percent of the trading in grain futures. ${ }^{197}$ In the case of the London commodity exchanges, although no precise figures are available, it has been estimated that option trades constitute well below five percent of the transactions in futures. ${ }^{198}$ The general view of the London exchanges has been that option trading as a whole has performed the useful economic functions of attracting additional funds to the futures markets and of adding flexibility in spreading risks, and that it has not had a negative effect on futures trading. ${ }^{199}$

It seems unlikely that option trading would have the effect of decreasing activity on the futures markets. Since option contracts are in a sense derived from futures contracts, they cannot exist without an underlying futures market. Most commentators have expressed the view that option trading will increase the volume of futures transactions, ${ }^{200}$

197. MEHL 10, 77.

198. 1974 House Hearings 179 (statement of Maurice Stockdale).

199. Id.

200. See id. 267; 1974 Senate Hearings 547; BEAN, Bower \& Co., The ECONOMic Role of TRADED OPTIONS 26 (1977). The effect of option trading on the futures markets would probably be greatly different if the options were assignable from one holder to another. This would lead to the existence of a secondary market in which option holders could liquidate their positions outside the context of the futures market. Most analysts have recommended strongly against allowing options on futures contracts to be assignable because of the possible impairment of both option and futures market liquidity. See, e.g., ADVISORY CoMMITTEE REPORT 2-3. This option assignability is to be distinguished from the transferability of options on an option exchange, which would 
the reasoning being that option grantors will be inclined to enter into futures contracts to hedge their option obligations, and that option purchasers who exercise their option rights will first obtain a futures contract from the grantor and then will enter into an offsetting futures contract to liquidate the position. In addition, an option holder may also enter into a futures transaction to hedge his option position. ${ }^{201}$

One possible problem that may arise is congestion in the delivery month of a futures contract. If the volume of profitable options outstanding is large, it may be difficult to exercise and offset the resulting futures position because of the large number of parties needing to liquidate their positions. If the condition is severe, there can be an artificial impact on the price of the underlying futures contracts, and it may be difficult to liquidate those contracts.

The primary means for dealing with congestion is to set the expiration dates of option contracts a sufficient length of time prior to the end of a delivery month to allow the option position to be liquidated before the final few days of the futures contracts. In the case of London options, for example, option contracts normally expire two to four weeks before the expiration of the underlying futures contracts. ${ }^{202}$ On the American exchanges, however, options on futures should expire before the first notice day in the delivery month for the underlying futures contract. In this way, options can be liquidated prior to the trading session in which the related futures contracts can be exercised, thereby avoiding any major congestion problems.

The area of greatest concern over the effect of option trading will be its potential for market concentration and price manipulation. Though the details of privilege trading in the nineteenth century are largely unavailable due to the lack of trading records, it has never been disputed that privileges were used to manipulate, if not to corner, certain markets. ${ }^{203}$ The danger of market concentration remains a serious concern, and the prevention of excessive concentrations constitutes perhaps the highest regulatory duty of the Commission. ${ }^{204}$

Some progress has been made since the 1860 s. The most critical factor will be that option trading will now be conducted on the domes-

allow an option holder to transfer his contract or to offset by entering into another transaction on the exchange. Id. 27.

201. 1974 House Hearings 267 (statement of John Clagett).

202. BEAN, BOWER \& Co., supra note 200 , at 42.

203. The 1934 Department of Agriculture study revealed the amassing of large positions through privileges in the several years prior to the great wheat market crash of 1933. MEHL 45-52. See also Ferris, The Great Corner, FARM Q., Spring 1966, at 106.

204. Some feel that preventing such market concentrations is really the only proper role for the Commission. See 1978 Senate Hearings 468 (statement of Dr. Hendrik Houthakker). 
tic exchanges and, probably more importantly, on the same exchanges that trade the underlying futures contracts. This will allow the exchanges to do what they could not do in the last century-that is, to monitor the open positions of each trader, both as to options alone and as to option and futures positions in the same commodity. Thus, the exchanges will be able to monitor and, if necessary, control large open positions in the marketplace.

Manipulation of prices for cash commodities or futures contracts is a felony under the Commodity Exchange Act, ${ }^{205}$ and violation of the speculative limits imposed on different futures contracts constitutes a misdemeanor. ${ }^{206}$ In addition, the Commission proposes a twenty-fivecontract reporting limit with respect to any given option position. ${ }^{207}$ However, in order to control market concentration effectively, the Commission must relate the limit on options to any related futures position in the same commodity. While the Commission has indicated its interest in removing the speculative limits in favor of another formula, ${ }^{208}$ its restrictions on large positions should take into account the relationship of futures and option positions.

So many unknown factors exist in the absence of actual experience in domestic option trading that it is impossible to develop a persuasive hypothesis regarding the impact of such trading on futures markets. Economic developments over the next few years may well have an impact on the types of persons engaging in option trading and on the volume of their activities. Whatever the actual experience under the pilot program, however, the Commission should develop thorough information-gathering systems and procedures for analyzing that information so that economists can measure the actual effects that option trading may have on the futures markets.

\section{Standards of Review for the Pilot Program}

The proposed pilot program in its present form has not determined with sufficient specificity the appropriate standards for evaluating the resulting option activity. However, it should be obvious that the data

205. 7 U.S.C. \& 13(b) (1976).

206. Id. § 13(c).

207. 42 Fed. Reg. 55,562 (1977) (to be codified in 17 C.F.R. $\$ 32.21(\mathrm{c})$ ). The Commission has admitted that this limit is arbitrary and may be changed in light of actual market experience under the pilot program. CFTC Staff Memorandum, supra note 142, at 12.

208. The Commission has proposed abandoning the traditional "position limits" in favor of a rule requiring each contract market to limit the position of any member in a maturing futures contract to not more than 25\% of the open interest in that contract unless the contract market determines that the holding of a greater position would not adversely affect trading in that contract. (This is commonly referred to as "Charlie's Rule.") 43 Fed. Reg. 15,438-41 (1978). 
collection to be implemented by the pilot program in an attempt to determine the economic benefits of commodity option trading will amount to an exercise in futility in the absence of appropriate standards for evaluating such data. As discussed above, the focus of data gathering under the pilot program will be on economic purpose, protecting consumers and determining the effect on futures markets. It follows that the review standards should have the same focus.

\section{A. Economic Purpose.}

In its evaluation of actual trading experience under the pilot program, the Commission should not view economic purpose as solely involving the motivation of particular option traders, but rather should examine the larger economic impact of this activity. Even if all option traders turn out to be purely speculators or investors, valid economic purposes can be found if such trading reduces the amplitude of price fluctuations on the underlying commodity futures markets or causes a general reduction in food prices or the costs of other consumer items. ${ }^{209}$ The Securities and Exchange Commission, in contrast with the CFTC, has not required that stock option trading involve more than an occasional hedger. ${ }^{210}$ Rather, the SEC has taken note of the fact that option trading can have substantial speculative aspects and has merely undertaken to monitor trading to see that it does not have an adverse impact on the securities markets. ${ }^{211}$

There is also a danger in asking the question of economic purpose in too small a forum. Obviously, if the Commission were to measure the economic benefit of option trading by its effect on the Commission's own budget, the pilot program would be sure to fail. If commodity options are actively traded under the pilot program, by whatever party and for whatever purposes, that should certainly evidence the existence of economic benefit to someone. In analyzing this issue, the Commission must decide which economic purposes it will recognize and how it will measure each one.

In any case, concentrating solely on the motives of market participants is too restrictive. It ignores broader, but no less legitimate, economic considerations. Instead of focusing on whether commodity

209. See BEAN, BOWER \& Co., supra note 200 , at 10 , in which a noted English firm recommended that the CFTC take account of the price stabilizing effects of option trading under its "economic purpose" test.

210. See SEC Investment Advisers Act Release No. 228, at 4 (Aug. 30, 1968), [1967-1969 Transfer Binder] FED. SEC. L. REP. (CCH) I 77,603; SEC Report on Put and Call Options 2 (1961).

211. See Gates, The Developing Option Market: Regulatory Issues and New Investor Interest, 25 U. Fla. L. Rev. 421,432 (1973). 
options are used primarily for speculative or other purposes, the Commission should conduct its evaluation in terms of the three levels of economic concern discussed above: first, whether options are useful to individual market participants in terms of investment, protection of other assets (such as futures contracts or physical inventories) ${ }^{\mathbf{2 1 2}}$ or as devices which facilitate futures trading (for example, as stop loss orders); ${ }^{213}$ second, whether option trading has a beneficial effect on the cash or futures markets in terms of increasing liquidity or reducing price fluctuations; ${ }^{214}$ and, finally, whether option trading plays any role in reducing consumer prices on items involving the commodities traded. $^{215}$ If an economic justification for option trading can be found under any of these rationales, and if it can be determined that no significant negative impact is imposed by such trading on the price discovery and risk allocation functions of the commodity futures markets, this author feels that an acceptable economic purpose will have been found.

\section{B. Consumer Protection.}

The proposed pilot program will present the Commission with a valuable opportunity to test the effectiveness of its new regulatory requirements in protecting the public from fraud and deception. In judging the success or failure of its new requirements, the Commission should consider seriously the use of domestic options as a standard against which to measure the sales practices relating to foreign and dealer options. For example, one measure of the unfair advantage taken of unsophisticated investors is the excessive markups that have been charged on London options in the past. ${ }^{216}$ By comparing information about premiums and commissions charged for foreign and dealer options with those charged for domestic options, the Commission should be able to determine whether the off-exchange options present an undue hazard to small investors. Second, the Commission should monitor the percentage of foreign and dealer option sales that are made by FCMs unaffiliated with any domestic exchange or the ICCH. If a great proliferation of nonmember FCMs occurs under the pilot program, the Commission should scrutinize their activities very closely. Finally, the Commission should conduct frequent and careful audits of any nonmember FCMs that are allowed to engage in option

212. See text accompanying notes 114-16 supra.

213. See text accompanying notes 129-30 supra.

214. See text accompanying notes 126-28 supra.

215. See text accompanying notes 117-18 supra.

216. See note 40 supra. 
sales. If it appears that the requirements set forth under the pilot program (particularly those relating to segregation of customer funds) are not being observed, the Commission may wish to reexamine its regulatory plan.

\section{Effects on Underlying Futures Markets.}

In the absence of a thorough economic analysis, it may be impossible to prescribe specific standards by which the impact of option trading on futures markets can be judged. However, the Commission should take certain factors into account in making a judgment as to this impact. First, it should examine the effect of option trading on liquidity in the futures markets. While the experience of the London exchanges indicates that option trading will not constitute a large percentage of the transactions involving a particular commodity, the Commission should establish a program for measuring the effect of option trading on liquidity in each underlying futures contract. ${ }^{217}$ A second factor to be examined is the possibility of congestion in the liquidation of either futures or options. As discussed above, ${ }^{218}$ the careful timing of expiration dates in option contracts should minimize or perhaps eliminate this problem with respect to futures, but the exchanges and the Commission should be alert to possible problems of congestion in the liquidation of option positions and the effect that such liquidation may have on prices in the underlying futures contract. Finally, it will be necessary for the Commission to establish a system for obtaining information about the combined futures and option positions of individual traders and for determining the level of concentration that threatens a market. This should be relatively easy regarding options traded on the same exchange as the underlying futures contracts. However, if options on physicals or options on markets other than those trading the underlying futures are allowed, the Commission will have a more difficult task in obtaining the requisite information. So long as the proper information can be obtained, however, the Commission will have a means of determining whether options are being used to influence artificially or to manipulate futures prices.

217. Not all parties agree that a reduction in trading volume in futures would be a bad result. See Comments of the Council on Wage and Price Stability, supra note 118, at 14. Such a reduction might indicate that options are a superior trading instrument for some purposes. However, an impairment of liquidity in futures trading (i.e., an insufficient number of buyers or sellers at any given price and time) that results in an inefficient or disruptive price discovery process would be a more serious concern for the Commission.

218. See text accompanying note 202 supra. 


\section{CONCLUSION}

Commodity option trading has had a long and turbulent history in the United States. Beginning with the "grain gamblers" of the $1860 \mathrm{~s}$ and continuing through the London option and "naked" option schemes of the 1970s, this history has been rocked almost constantly by moral outrage and scandal. In fact, there have been so many attempts to ban options altogether that it is remarkable they have survived at all. Somehow, in one form or another, commodity options have shown an amazing resilience.

The early difficulty with options (in the form of privileges and indemnities) was that they were neither banned nor controlled. The offcial attitude of "looking the other way" allowed options to realize their worst potential. There is little doubt that options were used by the grain speculators of the late nineteenth century to amass huge positions in a given commodity with which they could either manipulate prices or corner the market. The exchanges, which had the responsibility for guarding against such activities, were powerless to control options because they could not monitor the trading. Had options been recognized officially and subjected to the system of margins and clearinghouse guaranties that applied to futures trading, this history might have been totally different.

Over a century later, commodity option trading was again tainted by scandal. Neither subject to regulation by the domestic exchanges nor effectively regulated by state or federal securities agencies, the sale of commodity options was the object of widespread abuse. Again, the difficulty can be traced to the fact that commodity options were not traded on organized exchanges, and, therefore, customers were not protected by the time-tested safeguards of the boards of trade. Because of the extremely rapid expansion of the commodity option business, even the newly created CFTC, with its tremendous arsenal of jurisdictional reach and enforcement powers, could not provide an adequate substitute for exchange supervision. The result was that commodity options once more achieved their worst potential.

Commodity option trading now stands either at the final curtain or at the beginning of a new act. Thanks to the extensive scrutiny of options given by Congress in its 1978 oversight hearings, the regulatory problems have been clearly identified. However, despite the incessant difficulties in controlling option trading, there seems to be a renewed confidence in their economic potential. It could be that finally, after a century of doubt and suspicion, commodity options will be given a legitimacy that they have never before enjoyed. 
The CFTC seems to have chosen the best regulatory course-to adopt a program allowing option trading on domestic exchanges. In this author's opinion, only the commodity futures exchanges can provide the constant surveillance and monitoring of options that will avoid the problems of manipulation and fraud, while at the same time allowing options the maximum freedom to fulfill their natural economic potential in the marketplace.

One danger in the expected program for option trading is that it may be designed too narrowly to allow the basic forces of the marketplace to function and to permit options to reach their fullest economic capacity. Clearly, the CFTC has been charged with the serious responsibility of preventing further harm to American citizens as a result of option trading. The best way in which the Commission can perform this task, however, is to follow the system that has worked so well for futures trading: allow the exchanges to formulate market instruments and trading rules, and give the CFTC a right to approve contracts and rules and to monitor the exchanges. The CFTC has yet to formulate the economic standards, information goals and evaluative procedures to insure that its test will be valid. The Commission's success in completing this aspect of the proposed pilot program will also determine, to a substantial extent, the success or failure of this important test. 
